$$
\begin{aligned}
& \text { اثرات فعاليت كارخانه سيمان بهببهان بر جذب برخى عناصر غذايى و شاخصهاى } \\
& \text { بيوشيميايى در گَونهاى علفى خردل وحشى، ينيرك و جارو علفى }
\end{aligned}
$$

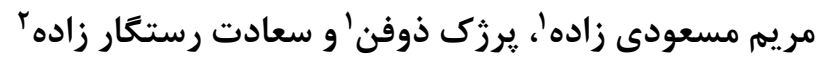

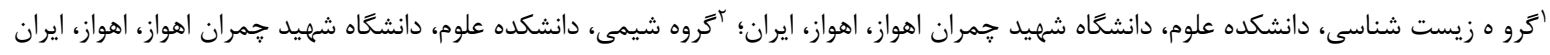

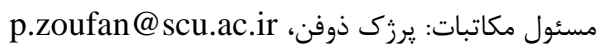

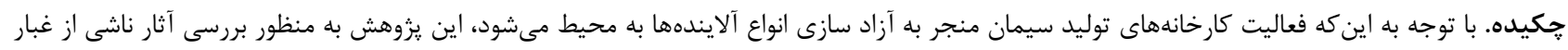

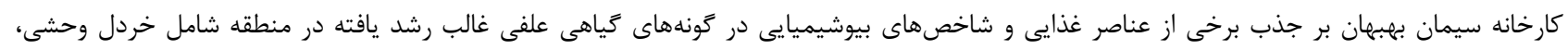

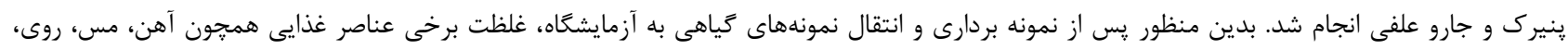

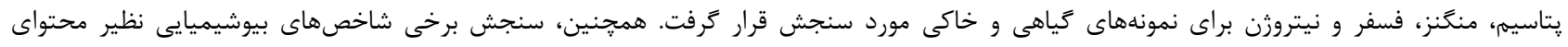

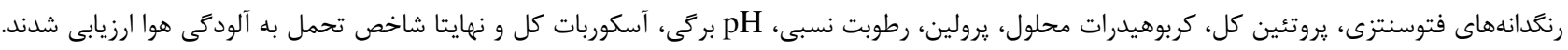

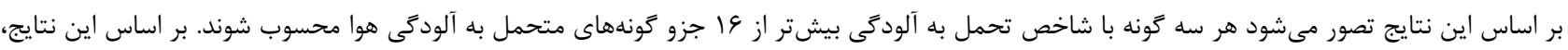

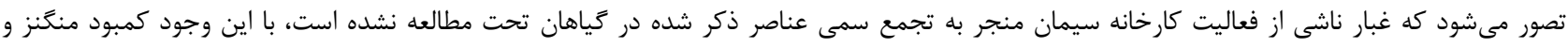

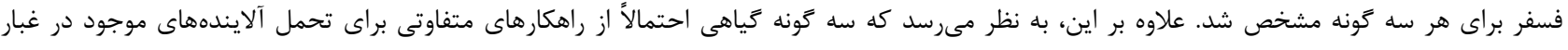
منطقه بهره مى كيرند.

وازههاى كليدى. آلودگى هوا، تحمل، تجمع عناصر، شاخص بيوشيميايى، كياهان علفى

\title{
The effects of Behbahan cement factory activity on the absorption of some nutrients and biochemical responses in herbaceous plants Sinapis arvensis, Malva neglecta and Bromus tectorum
}

\author{
Maryam Masoudizadeh ${ }^{1}$, Parzhak Zoufan ${ }^{1}$ \& Saadat Rastegarzadeh ${ }^{2}$ \\ ${ }^{1}$ Department of Biology, Faculty of Science, Shahid Chamran University of Ahvaz, Ahvaz, Iran; ${ }^{2}$ Department of \\ Chemistry, Faculty of Science, Shahid Chamran University of Ahvaz, Ahvaz, Iran \\ Correspondent author: Parzhak Zoufan, p.zoufan@scu.ac.ir
}

\begin{abstract}
The cement production activities leads to the release of different pollutants into the environment. This research was conducted to study the effects of dust particles released by Behbahan cement factory on the absorption of some nutrient elements and biochemical parameters in dominant herbaceous species grown in this area, including Bromus tectorum, Malva neglecta and Sinapis arvensis. Plant samples were transferred to the laboratory. Then, the concentrations of some nutrient elements, such as $\mathrm{Fe}, \mathrm{Cu}, \mathrm{Zn}, \mathrm{K}, \mathrm{Mn}, \mathrm{P}$ and $\mathrm{N}$, were assayed in plant and soil samples. Moreover, some biochemical parameters, such as photosynthetic pigments, total protein, soluble carbohydrates, proline, relative water content, leaf $\mathrm{pH}$ total ascorbate and air pollution tolerance indexes (APTI), were evaluated. Based on these results, it is supposed that three plant species are tolerant to air pollution with an APTI higher than 16. In addition, it seems that the dust released by the cement factory has not led to a toxic accumulation of the elements in the studied plants. The deficiency of $\mathrm{Mn}$ and $\mathrm{P}$ was determined for three plant species. On the basis of biochemical analysis, it is supposed that these plant species possibly use different strategies to tolerate the pollutants in this area.
\end{abstract}

Keywords. air pollution, biochemical parameters, herbaceous plants, nutrients accumulation, tolerance 
آسيبهاى غشايى فرايندهاى مختلف سلولى را دجار اختلال

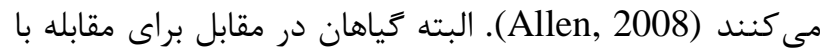

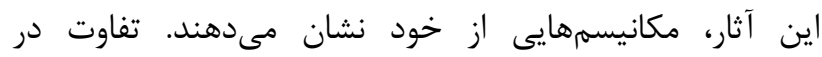

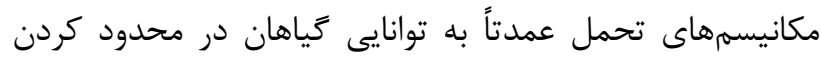

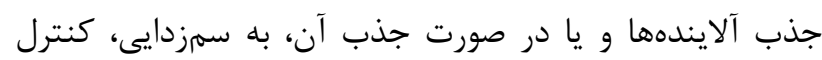
سوخت و ساز و دفع سموم مربوط مىشود. كاهى آلاينده

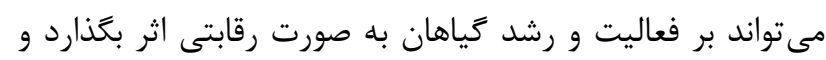

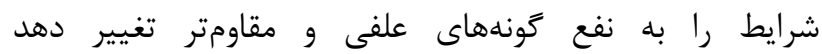
(Fischerová et al., 2006). برخى مطالعات نشان دادند كه آلايندهاى ناشى از فعاليتهاى صنعتى نظير صنعت سيمان

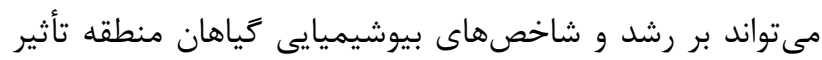

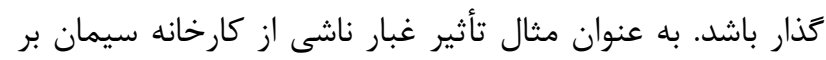

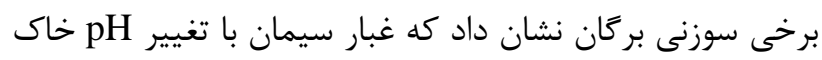

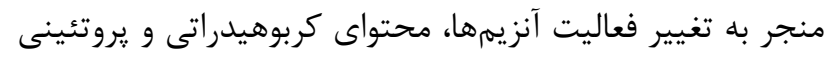

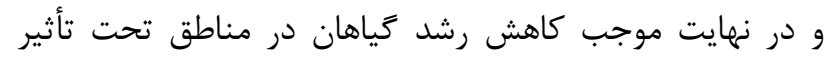

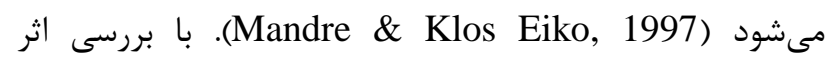

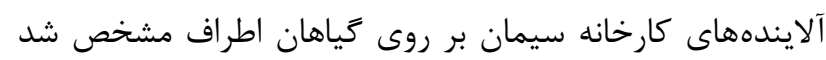

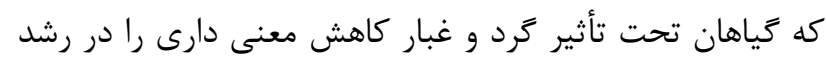

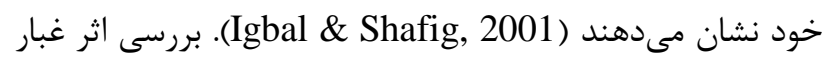

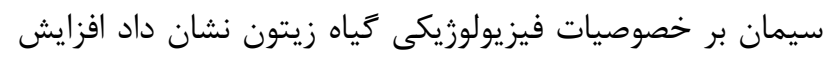

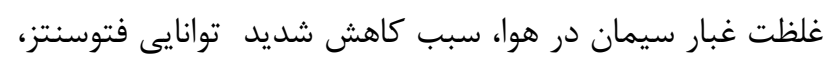

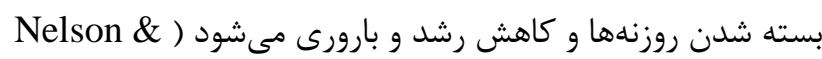

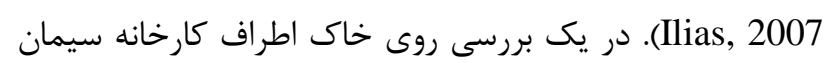

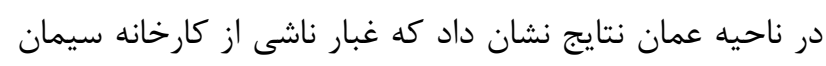

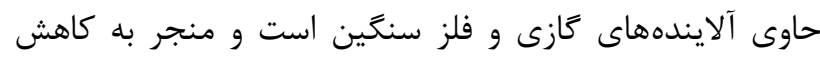

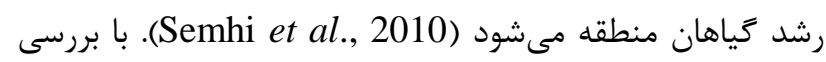

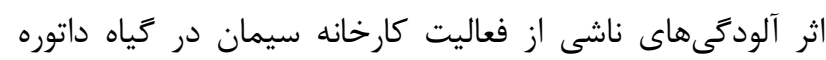

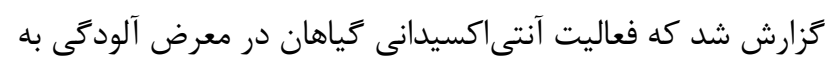

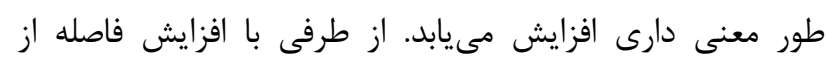

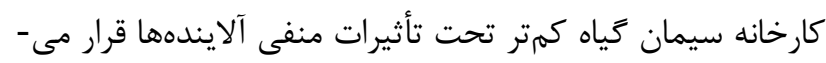

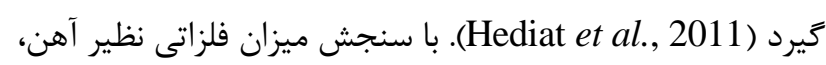

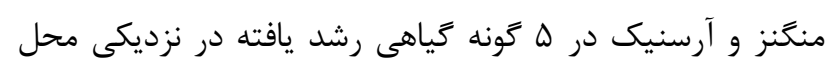

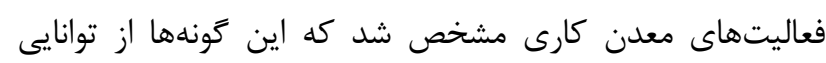

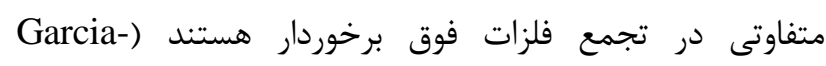

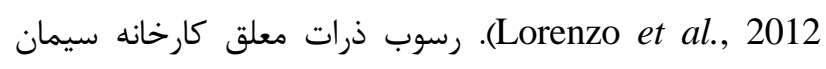
بهببهان بر درختان كنار رشد يافته در اين منطقه باعث كاهش درات داري

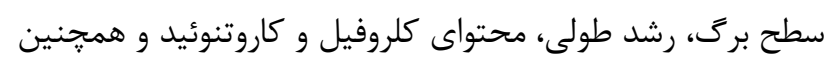

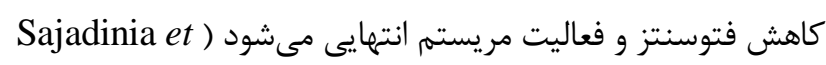

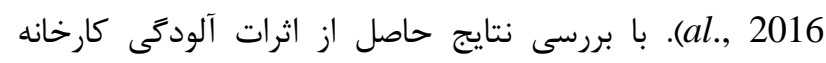

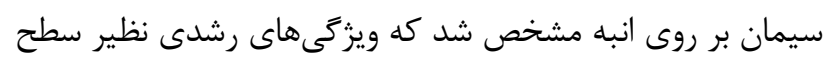

مقامله

كسترش روز افزون شهرها، رشد سريع شهرنشينى و فعاليت-

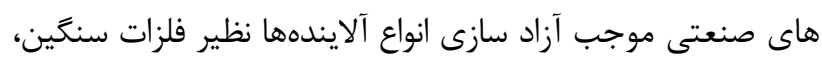

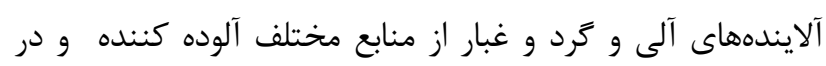

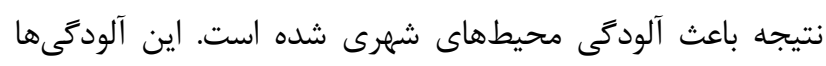

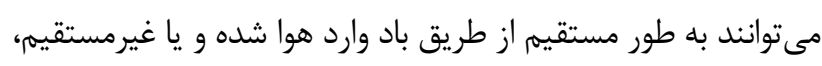

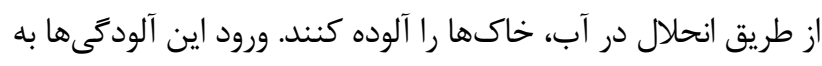

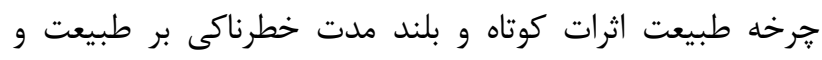

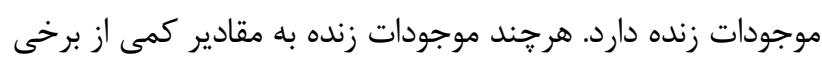

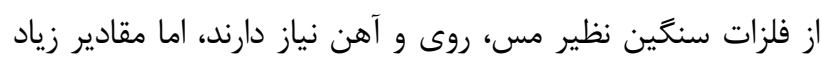
آنها مى تواند براى آنها مخرب باشئ (آندي (Buszewski et al., 2000).

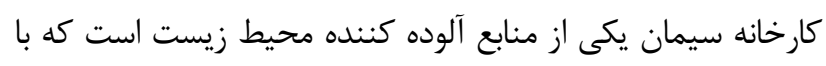

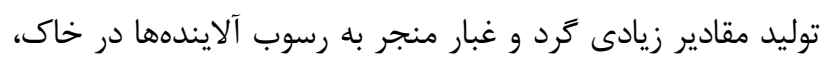

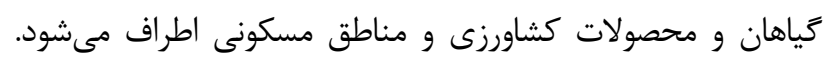

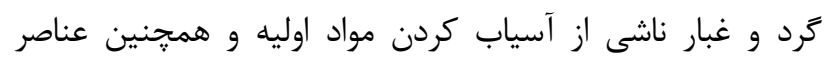

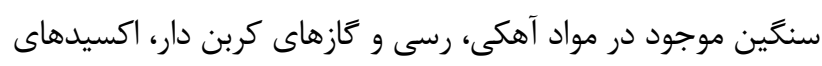

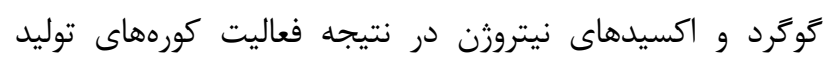

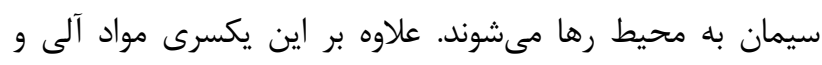
فلزات سمى ناشى از سوختن ضايعات نفتى و آلى موجود در موري مواد

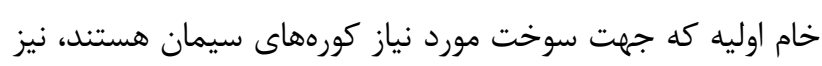

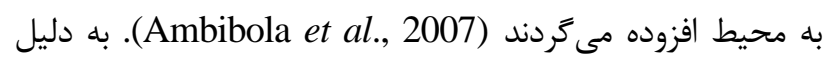

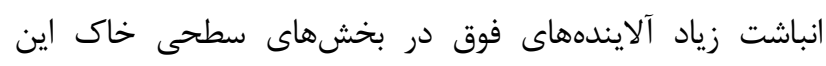

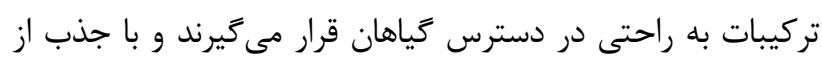

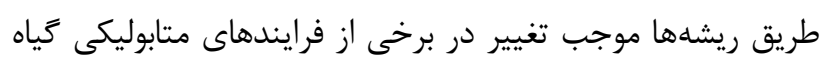

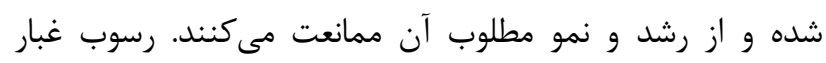

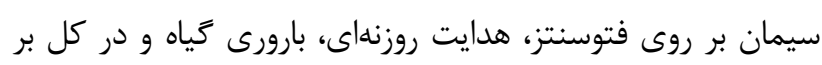
شاخصهاى فيزيولوزيكى كياه اثر كذار است (

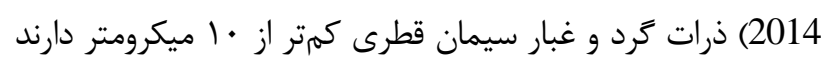

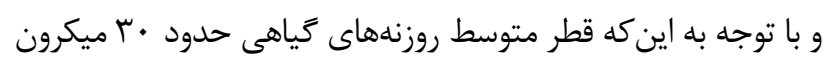

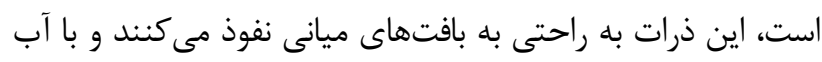

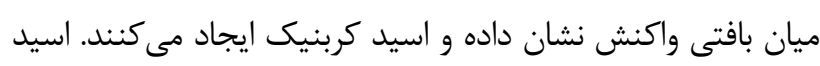
توليد شده بر اجزاى درون سلولى، خصوصا كلرويلاست و كوتيكول

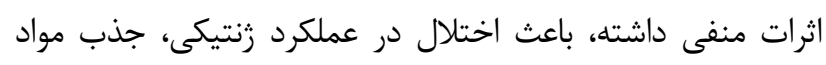

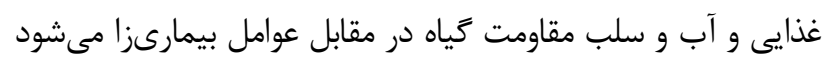
(Mandre \& Klos Eiko, 1997) سنخين ناشى از آسياب كردن مواد اوليه در كارخانه سيمان

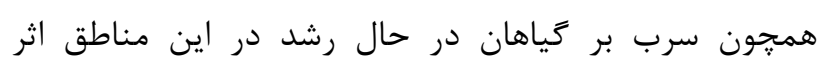

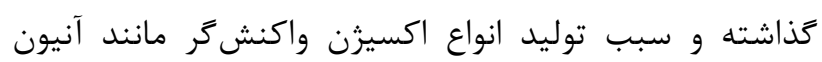
سوير اكسيد (O)

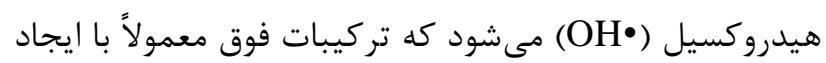


يزوهش حاضر در جنوب شرقى استان خوزستان، شهر بهبمهان

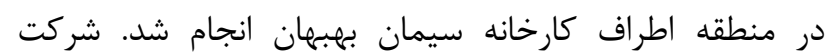

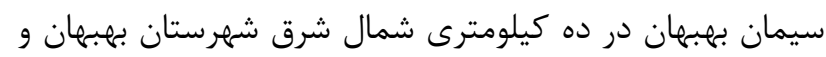

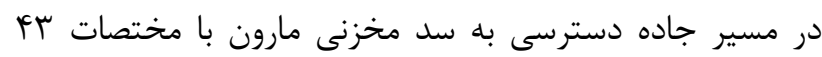

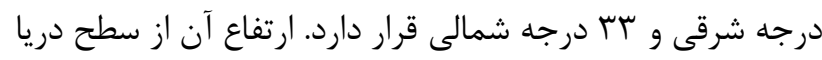

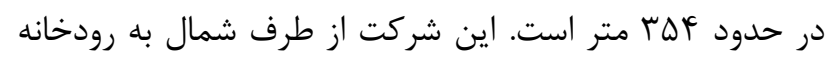

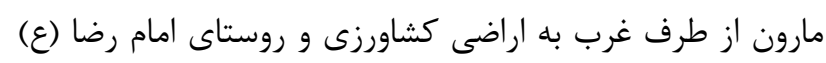

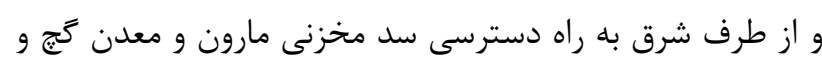

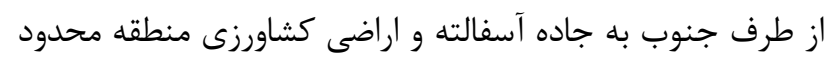

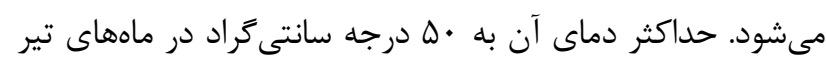

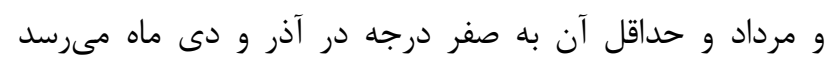
http://www.behcco.ir/HomePage.aspx?TabID=4784) . (\&Site=DouranPortal \&Lang=fa-IR نمونه بردارى و عصاره كيرى از كياه جهت سنجش عناصر

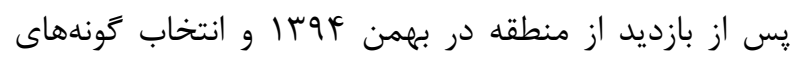

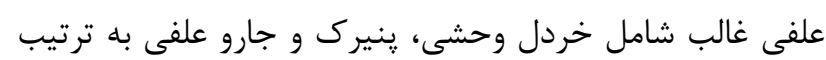

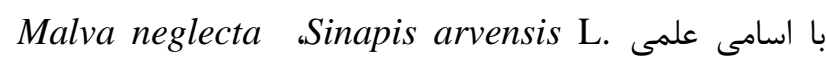
Bromus tectorum L.و Wallr.

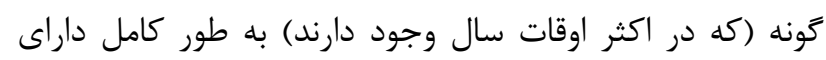

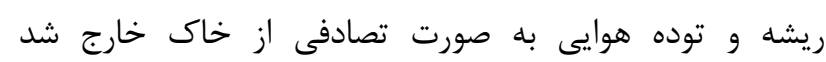

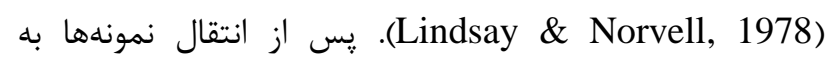

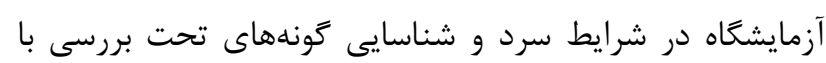

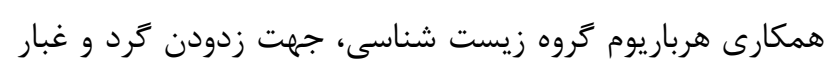

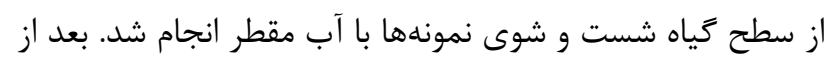

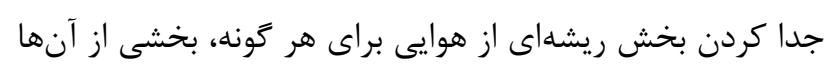

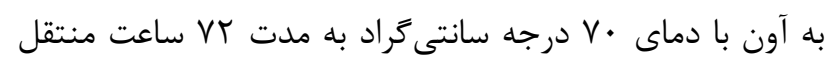

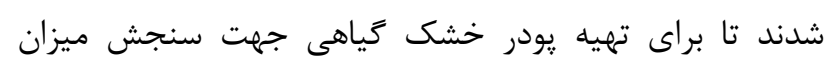
جذب عناصر و همين طور ميزان كربوهيدرات كل استفاده شوند.

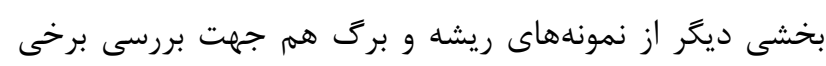

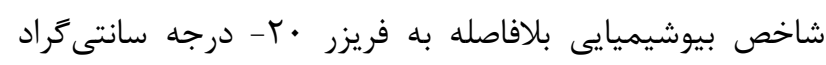

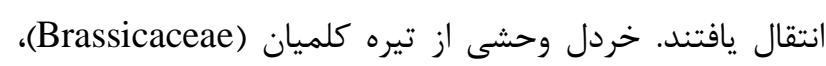

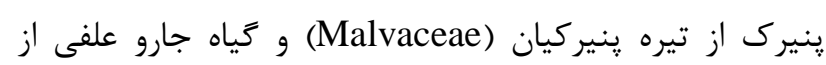
تيره كندميان (Poaceae) است.

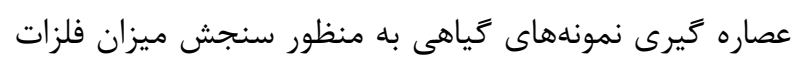

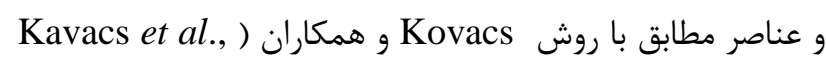

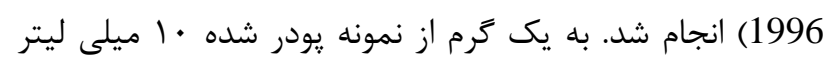

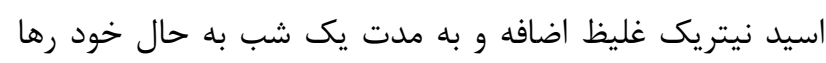

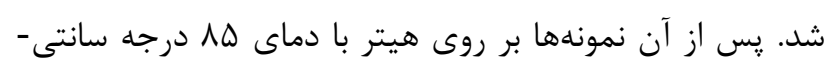

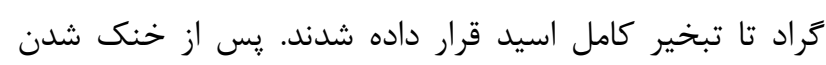

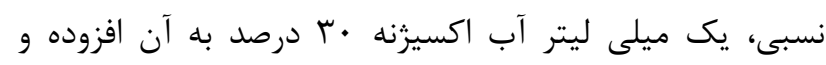

بركى و محتواى رنكدانهاى كاهش معنى دارى را نشان مىدهند (Dwivedi \& Dubey, 2017) رشد يافته در مناطق آلوده شهرى مشخص شده كه اين كياهان با ديا

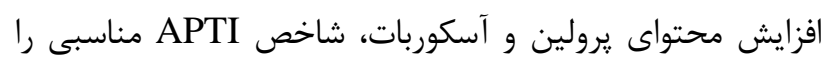

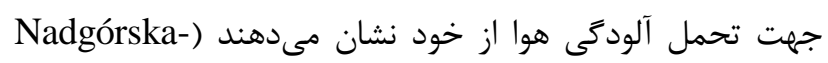

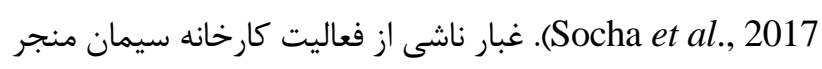

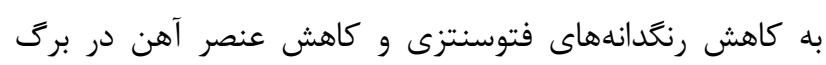

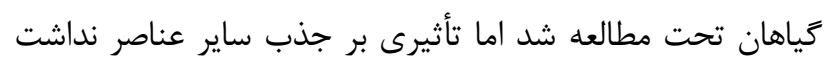

(Siqueira-Silva et al., 2017) با توجه به مشكلات زيست محيطى حضور آلايندهها در

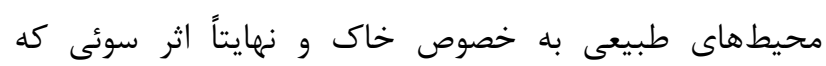

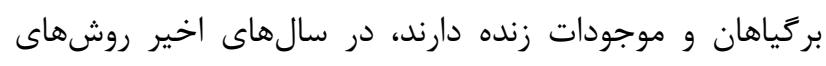

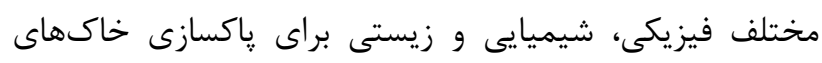

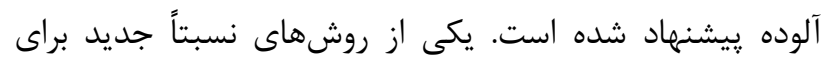

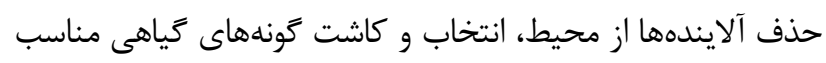

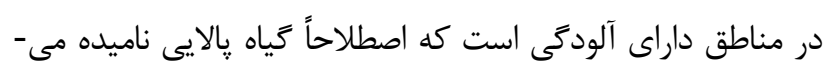

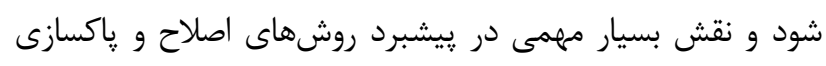

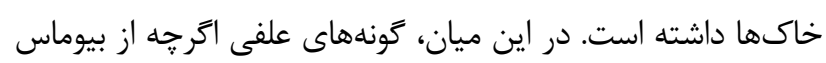

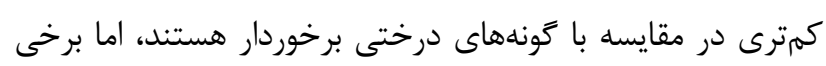

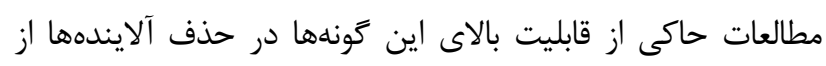

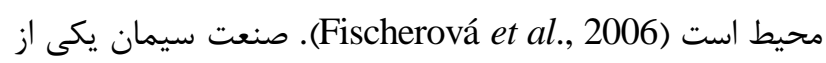

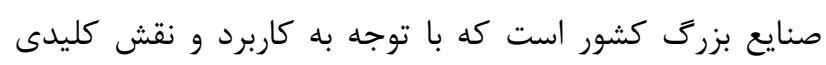

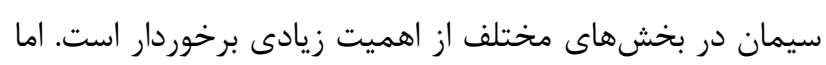

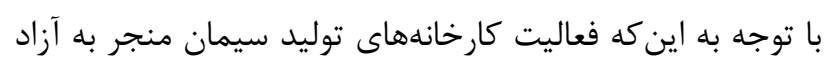

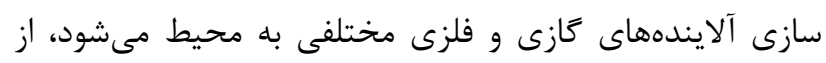

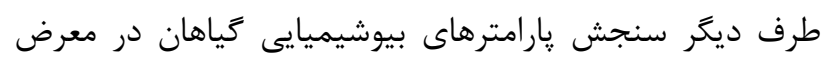

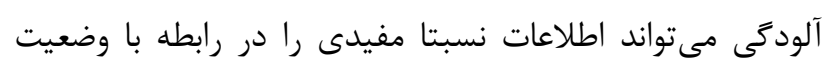

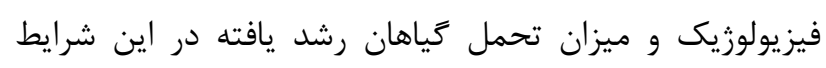

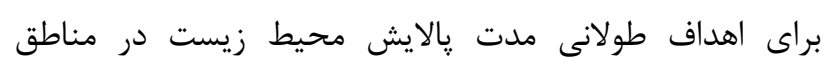

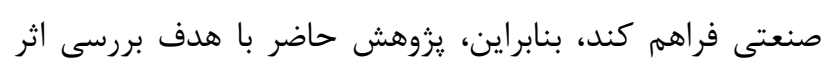

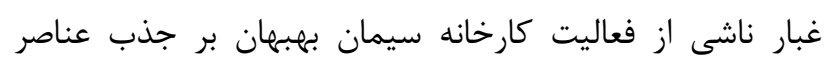

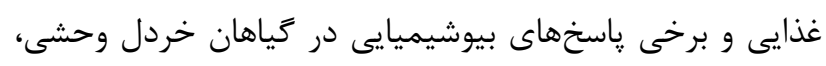

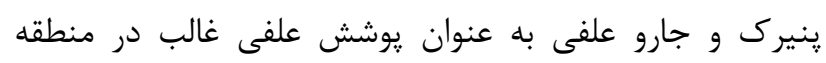

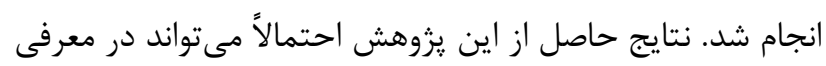

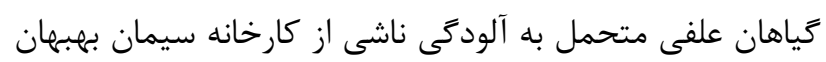

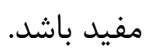
مواد و روشها مشخصات جغرافيايى منطقه تحت مطالعه 
در نمونههاى خاك برحسب ميلى گرم بر كيلوگرم وزن خشك

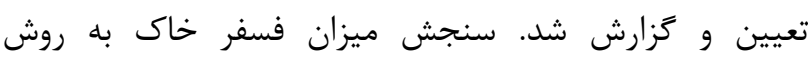

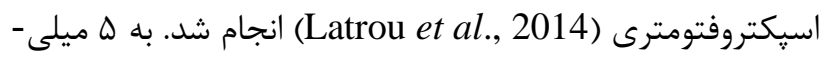

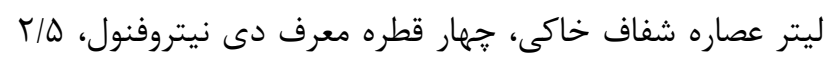

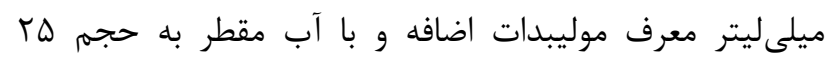
ميلىليتر رسانده شد. سيس، با كمك دستخاه اسيكتروفتومتر ميزان جذب نمونهها در طول (WPA (Biowave) biochrom)

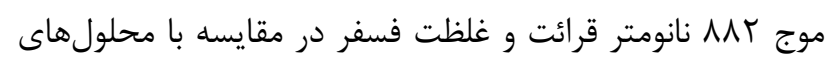
استاندارد KH2PO بر حسب ميلى خاك تعيين شد. براى سنجش ميزان نيتروزن و يتاسيم خاك از

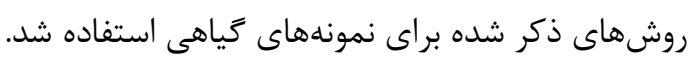
تعيين فاكتور انتقال (Translocation factor) و فاكتور تغليظ ندونياي

زيستى (Bioconcentration factor) فاكتور انتقال (TF) ميزان انتقال فلز سنگين را از ريشه به

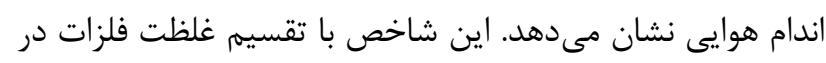

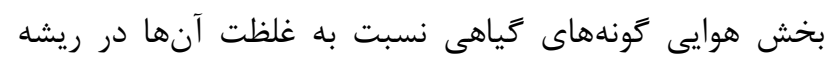
محاسبه شد. فاكتور تغليظ زيستى (BF) با محاسبه نسبت

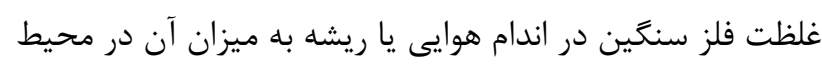

خاى محاسبه شد (Branquinho et al., 2007).

سنجش pH عصاره بركى

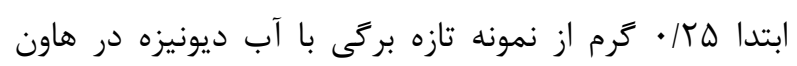

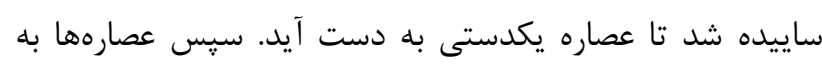

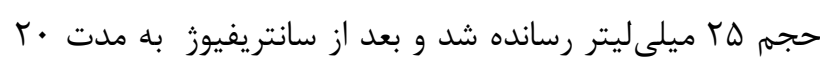

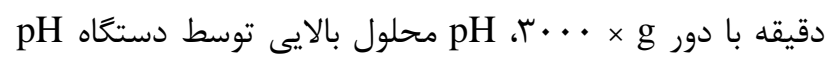
متر اندازمخيرى شد (Pathak et al., 2011).

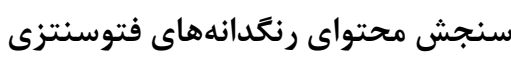

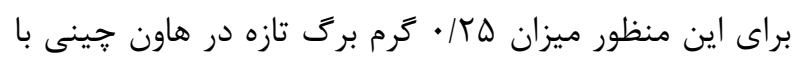
• ا ميلىليتر استون •م درصد در شرايط تاريكى روى يخ ساييده شد. يس از آن به كمك كاغذ واتمن شماره 1 صاف و ميزان جذب عصاره با كمك دستگاه اسيكتروفتومتر در طول موجهاى

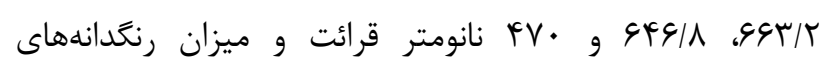
كلروفيل a, وزن تر بيان شد (Lichtenthaler, 1987).

اندازه گيرى درصد محتواى آب نسبى برى ( Relative water (content; RWC

ابتدا • ا كرم نمونه برك تازه توزين شد. يس از آن نمونهها در

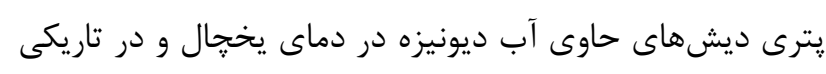

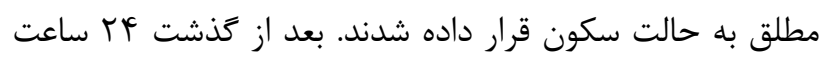

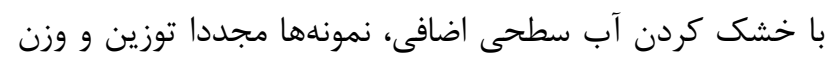
فوق به عنوان وزن تورزسانس در نظر گرفته شد. سيس با قرار
مجددا تا تشكيل رسوب زلهاى حرارت داده شد. رسوب حاصل با مقدارى آب دوبار تقطير شستشو و به كمك كاغذ واتمن شماره بFا، صاف و درنهايت به حجم • له ميلىليتر با آب دوبار تقطير

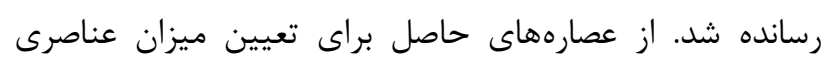
مانند آهن، سرب، مس، روى و منگَنز (با دستخاه جذب اتمى GBC استاندارد مربوط به هر عنصر استفاده و ميزان هر عنصر بـ به به به صورت ميلى گرم بر كيلوگرم وزن خشك گياهى نشان داده شد. براى سنجش ميزان فسفر در نمونههاى زياهى ه ه ميلى ليتر

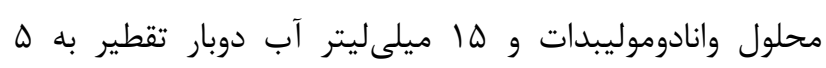
ميلى ليتر عصاره شفاف افزوده و سيس جذب عصارهها با روش وريد اسيكتروفتومترى در طول موج • FV نانومتر قرائت و مقدار فسفر در بخش هوايى يا ريشهاى با كمك منحنى استاندارد $\mathrm{KH}_{2} \mathrm{PO}_{\mathrm{M}}$ بر حسب ميلى گرم بر كيلوگرم وزن خشك تز سنجش ميزان عنصر گتاسيم در عصارههاى گياهى از دستخاه

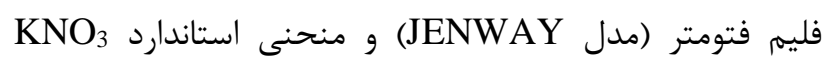
استفاده شد. اندازهيرى درصد نيتروزن گياه، مطابق روش

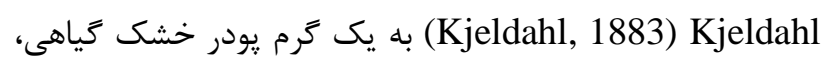
r/9 زرم كاتاليزور (به صورت سولفات مس آبدار و سولفات

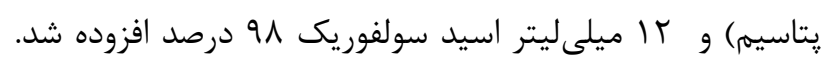

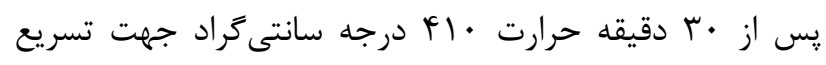
هضم اسيدى، به هر نمونه ••ه ميلىليتر آب دوبار تقطير اضافه

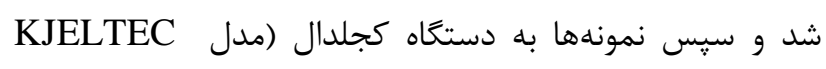
1030 Analayzer

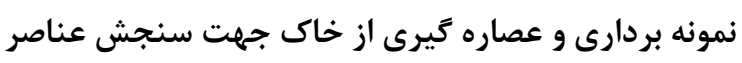

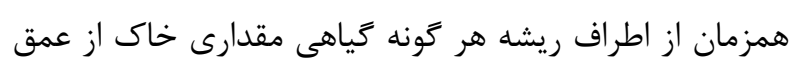

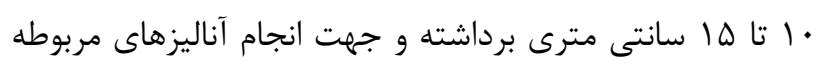
به آزمايشعاه منتقل شد (Yanqun et al., 2004). نمونههاى خاكى مربوط به هر زونه با هم مخلوط و به مدت يك هفت هفته در

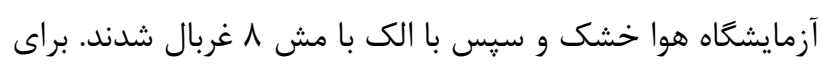

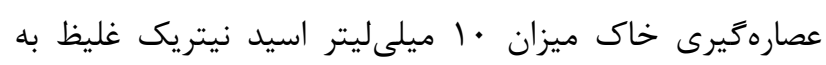
يك گرم خاك هوا خشك افزوده و سيس بر روى هيت هيتر با درجه حرارت هم درجه سانتى گراد قرارداده شد. يس از تبخير اسيد،

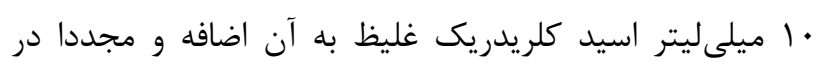

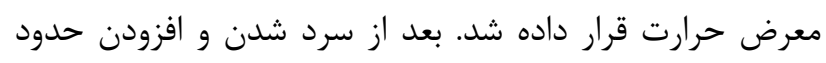

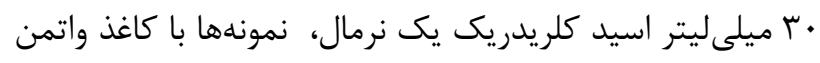

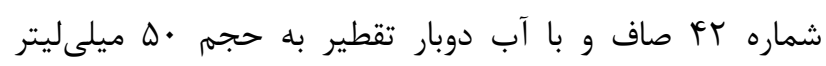

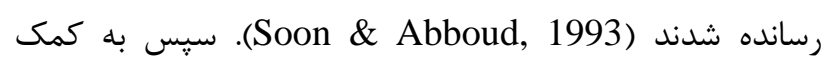
دستخاه جذب اتمى و با در نظر زرفتن منحنى استاندارد مربوطه ميزان عناصرى جون آهن، مس، روى، سرب و منگنز به فرم كل 
جداسازى يروتئينهاى محلول مطابق با روش Qiu و همكاران

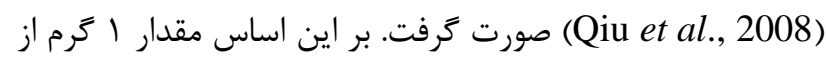

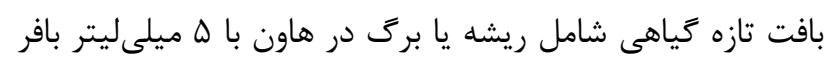

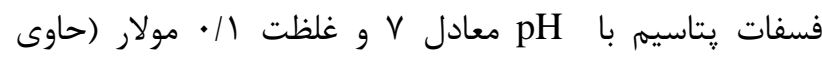
• يك درصد و Polyvinylpyrrolidone

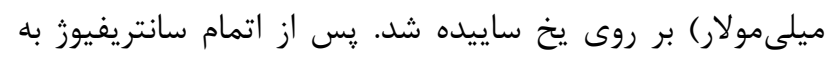

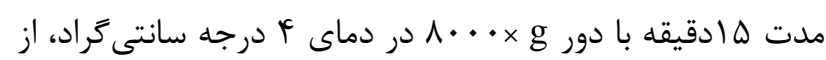

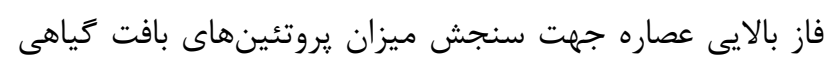

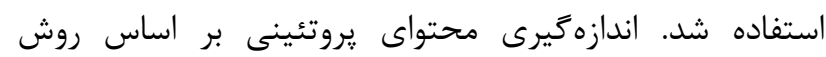
(Bradford, 1976) Bradford

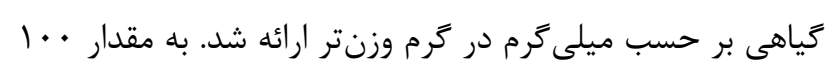

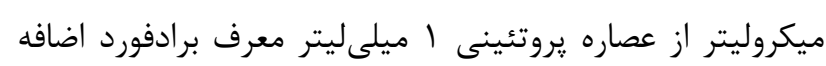

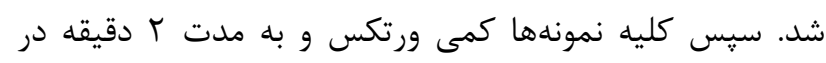

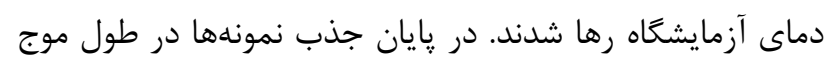

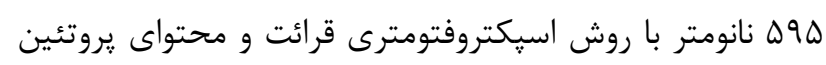

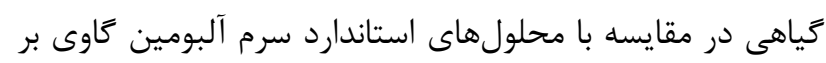

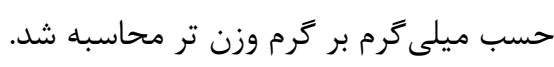

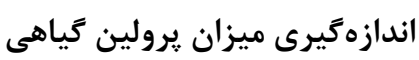

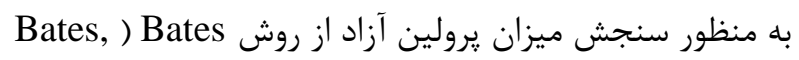

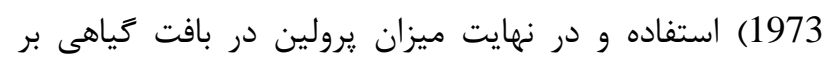

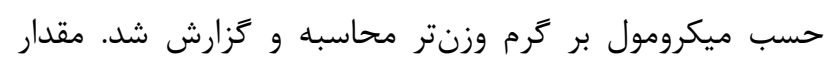

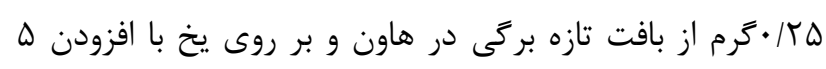

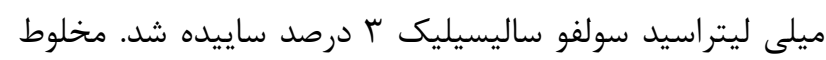

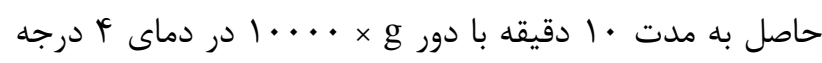

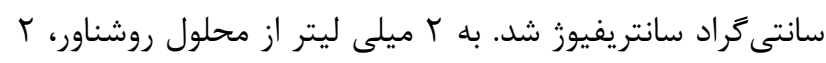

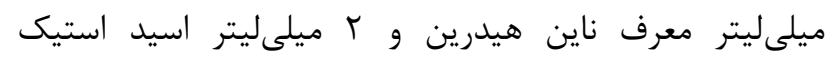

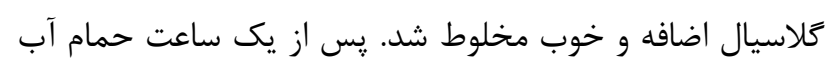

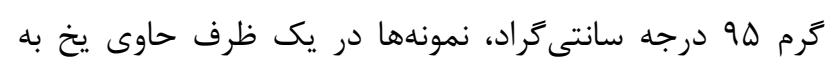

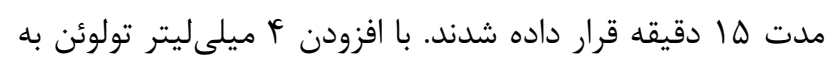

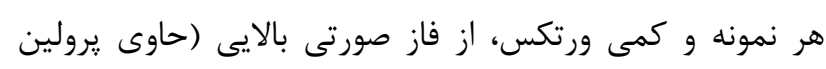

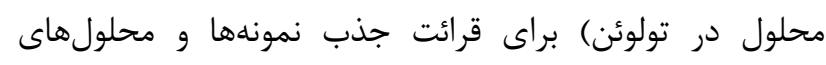

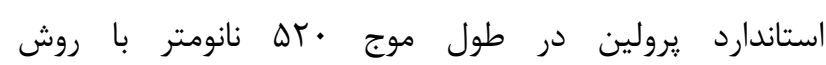

$$
\text { سنجش كربتروفتومترى استفاده شد. }
$$

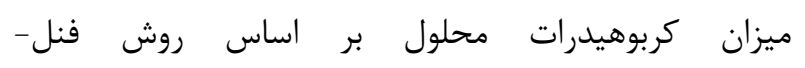

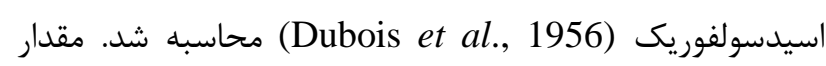

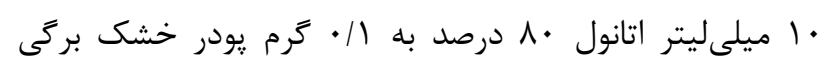

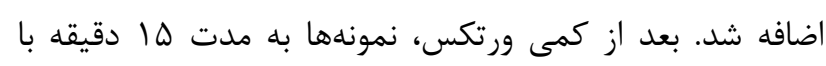

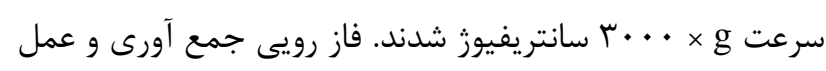

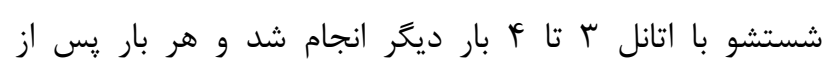

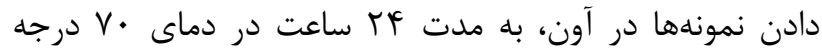

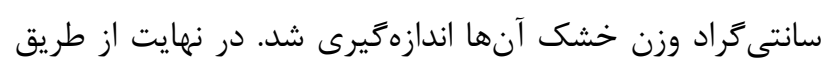
رابطه زيردرصد RWC محاسبه شد (Pathak et al., 2011) \% RWC = (W f -Wd) 100/ (Wt - Wd) (1) (1)

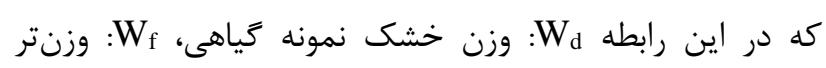

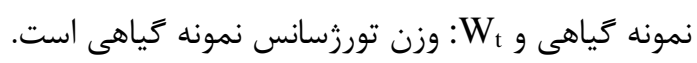
اندازه كيرى ميزان آسكوربيك اسيد

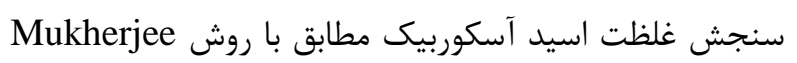
و و انجام (Mukherjee \& Choudhuri, 1983) Choudhuri شد. ميزان ها • گرم وزن تر برگى به همراه • ا ميلى ليتر محلول

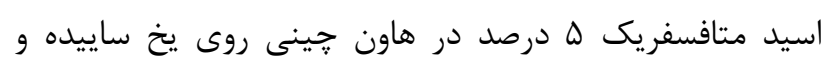

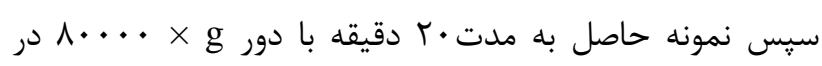

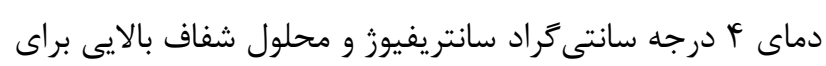

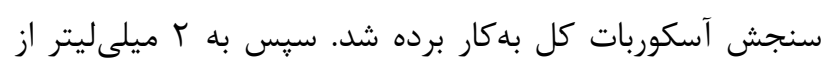

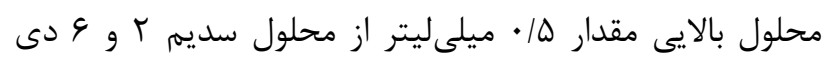

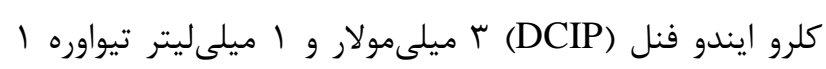

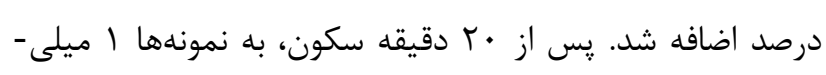

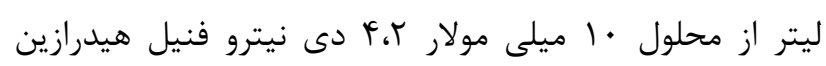

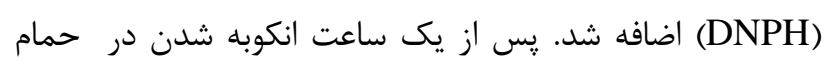

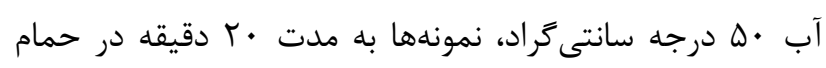

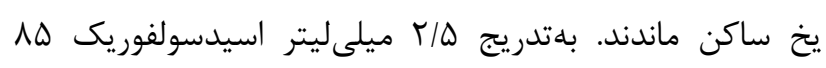

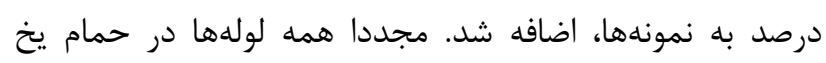

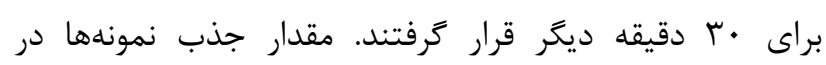

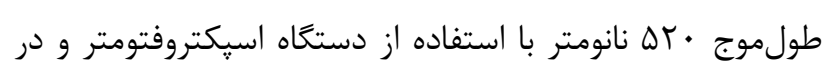

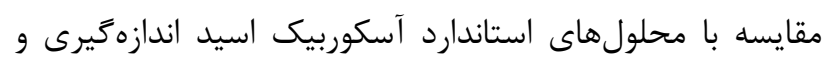

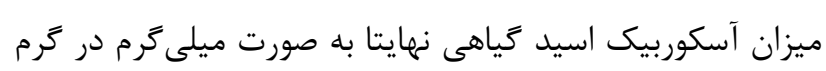
وزن تر بيان شد.

Air pollution ( محاسبه شاخص تحمل بيه آلودتى هوان (tolerence index اين شاخص در رابطه با كياهان منطقه آلوده بهمنظور تعيين

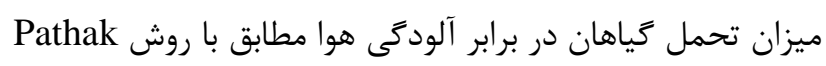

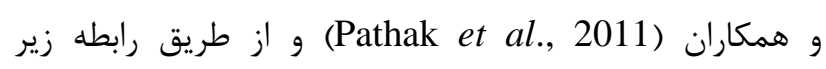
APTI = [ رحاسبه شد. كه در اين رابطه، APTI : شاخص تحمل كياه به آلود آلى هوا،

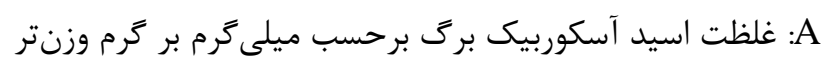

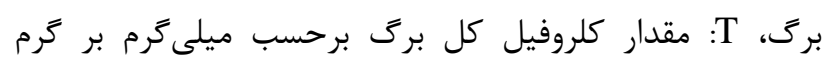

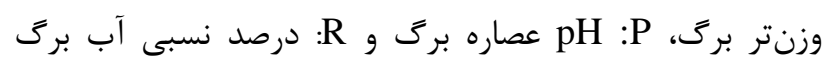
است. استخراج و سنجش :روتئينهاى محلول كياهى 
يك محاسبه شد. اندامهاى هوايى ينيرك و جارو علفى ميزان

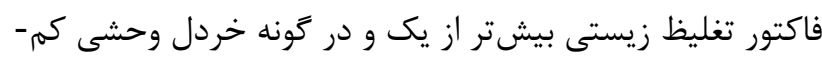

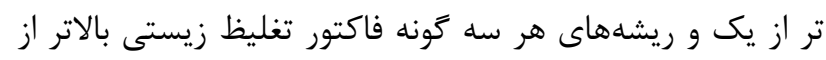
يكى براى آهن نشان دادند. همان طور كه در جدول 1 مشاهده ميشود بيشتر دادئرين مقدار

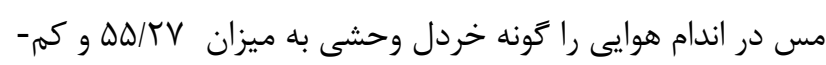

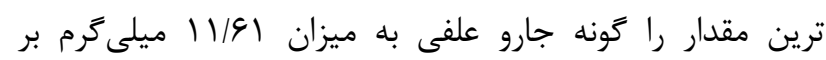

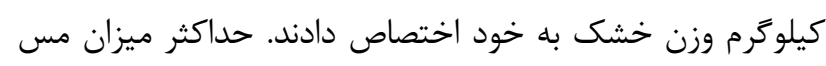

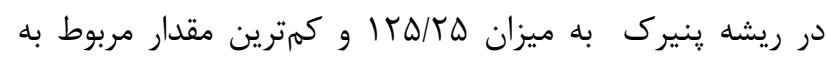

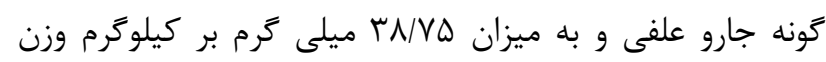

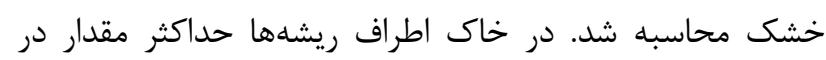

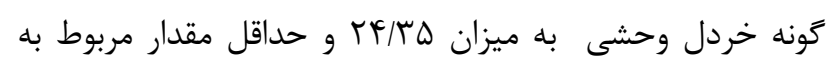

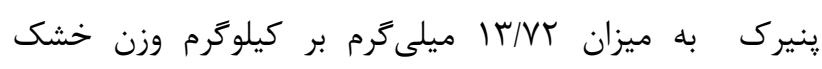

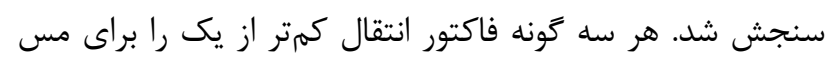

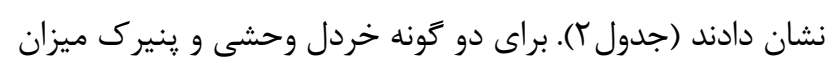

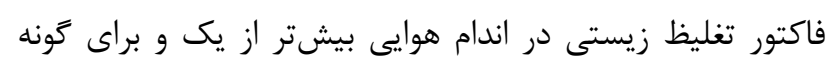
جارو علفى كمتر از يكى بود. همجنين نتايج نشان داد كاد كه ميزان

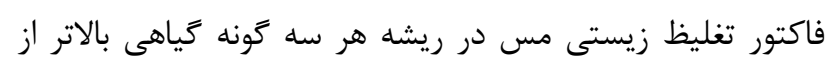

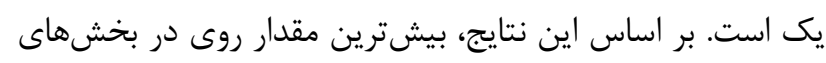

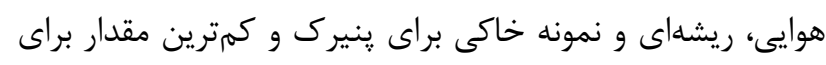

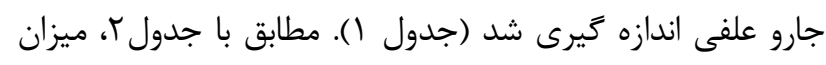

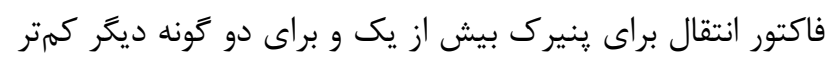

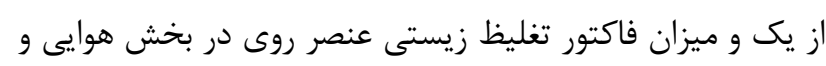
ريشهاى براى هر سه كونه كمتر از يك محاسبه شد.

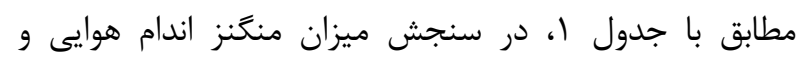

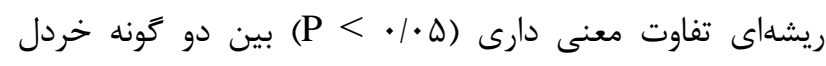

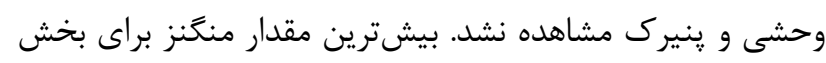
هوايى و ريشهاى جارو علفى سنجش شد شد. با بررسى ميزان منكَنز

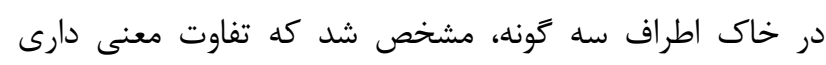

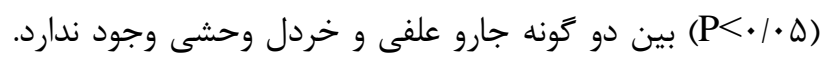

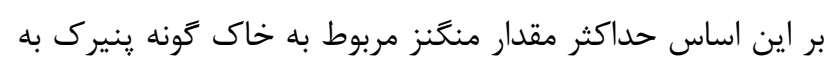

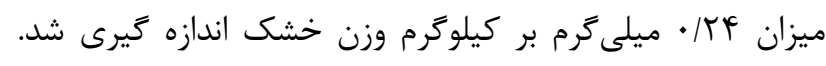

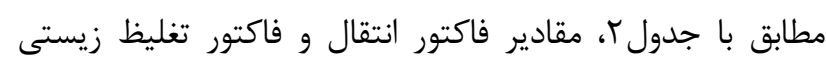

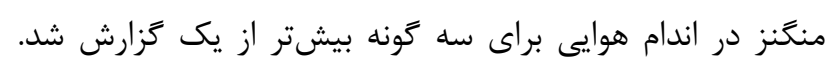

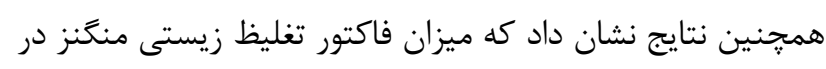

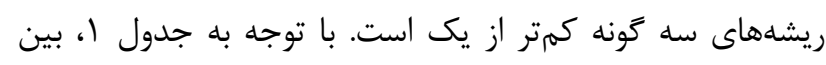

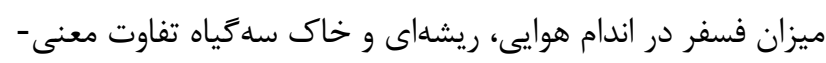

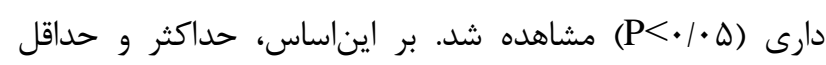

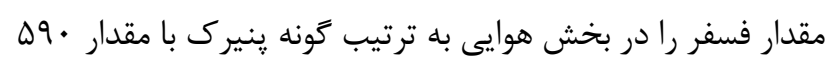

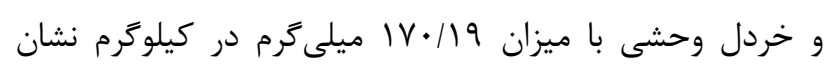

1. مانتريفيوز محلول روشناور جمع آورى و حجم نهايى با اتانل

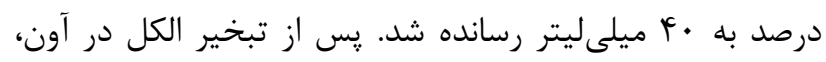

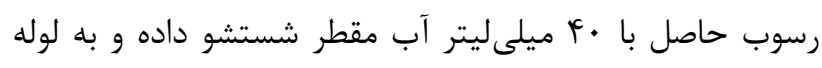

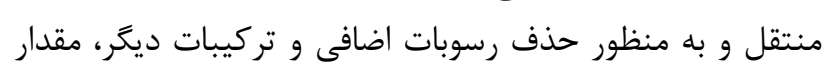

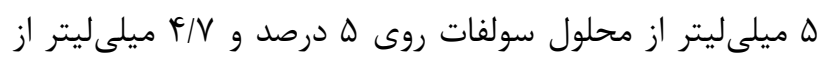

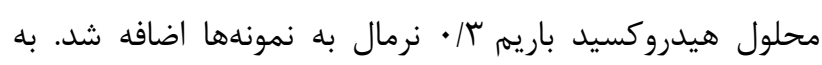

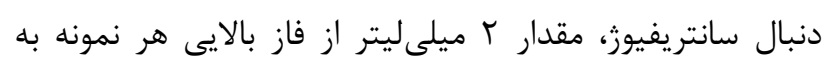

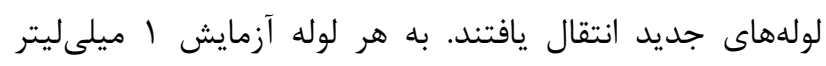

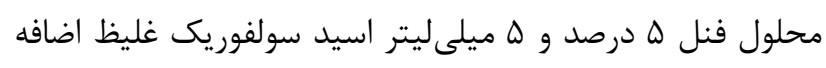

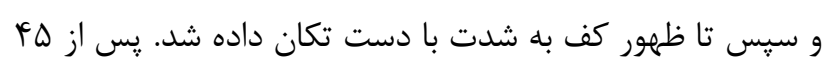

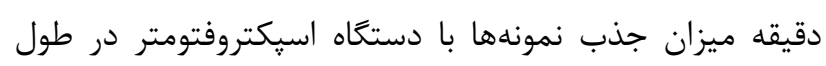

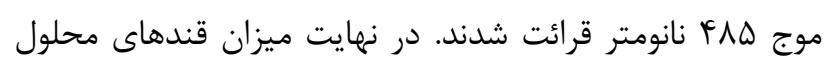

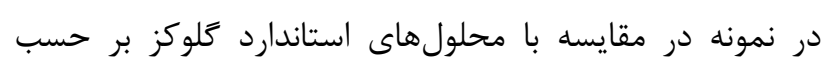

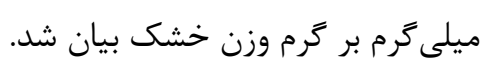
تجزيه و تحليل آمارى تنتايج به دست آمده با استفاده از نرم افزار

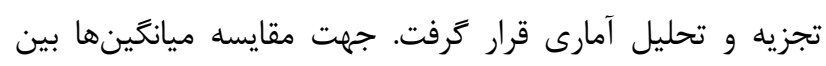

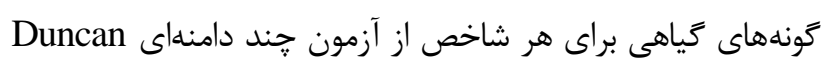

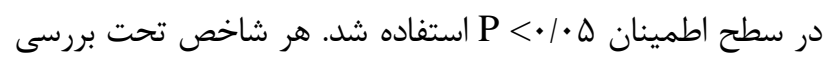
در اين تحقيق به صورت ميانكَينى از سه تكرار در نظر كرفته شد. شاند

\section{نتايج}

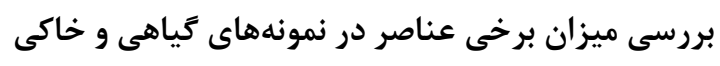

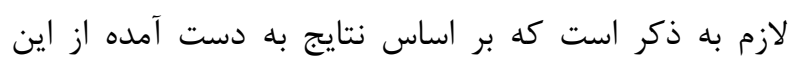

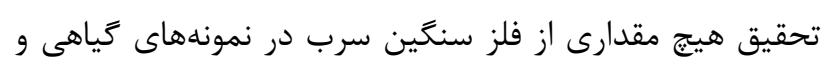

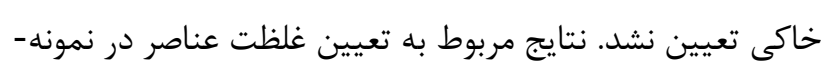

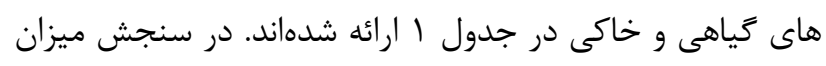

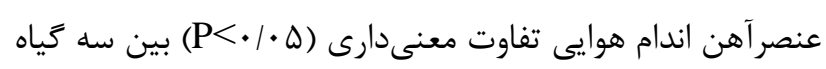

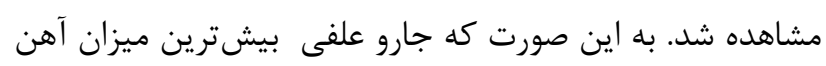

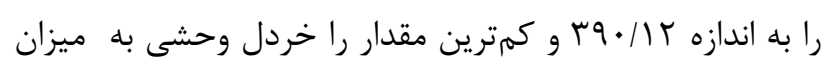

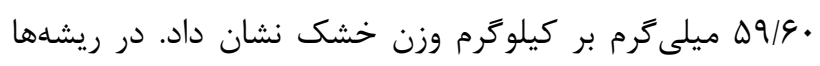

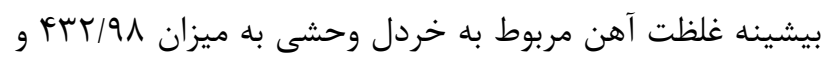
كمينه آن مربوط به جارو علفى به ميزان

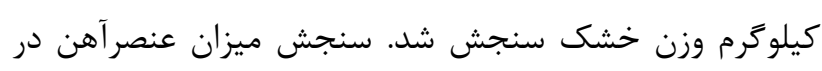

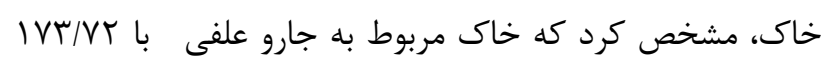

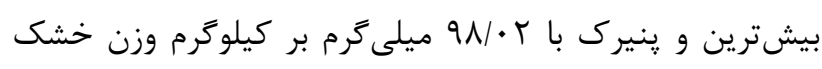

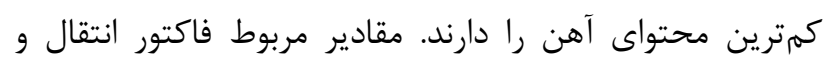

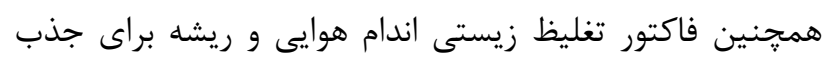

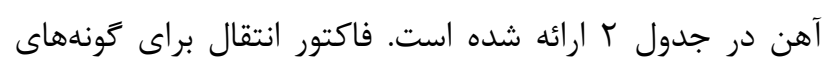

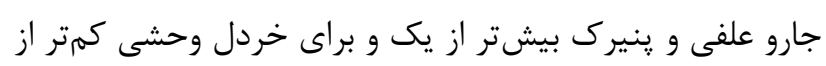


V/q. و براى جارو علفى برابر با V/DD سنجش شد. بر اساس

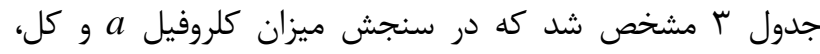

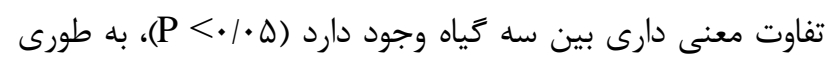

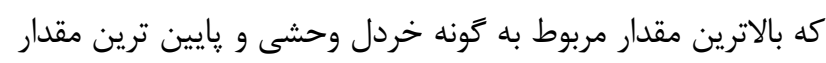

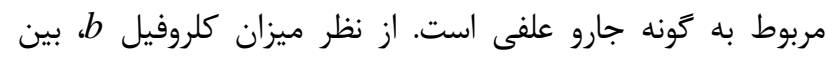

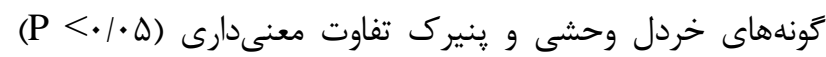

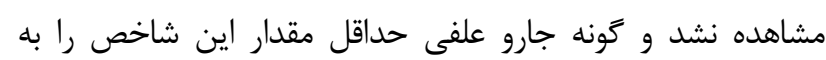

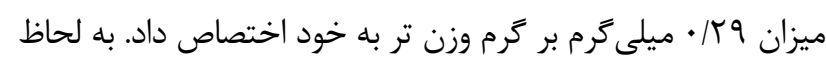

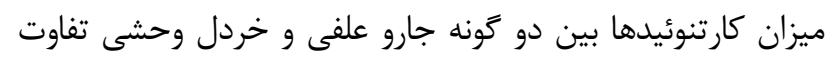

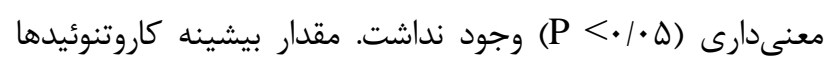

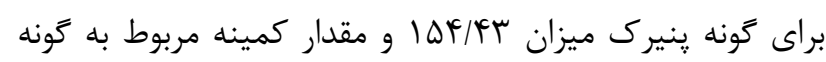

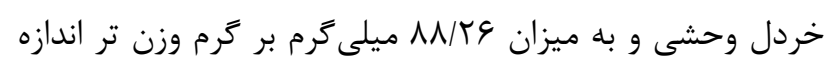

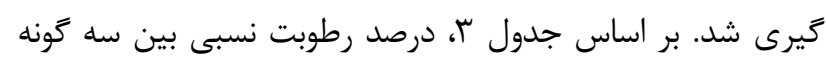

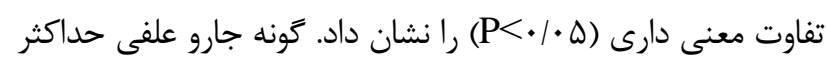

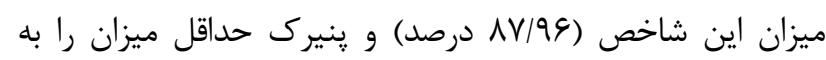

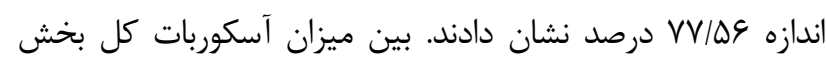

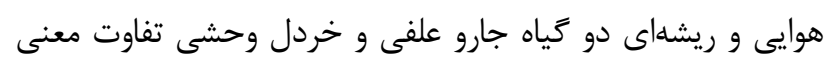

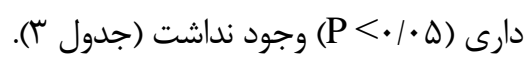

دادند. در ريشهها و خاك گَونه جارو علفى بيشترين مقدار و خردل وحشى كمترين محتواى فسفر سنجش شد. مطابق با جدول

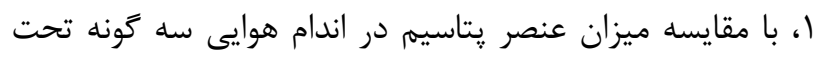

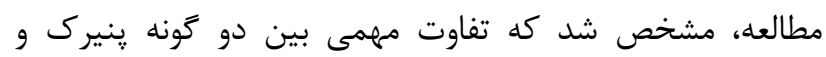

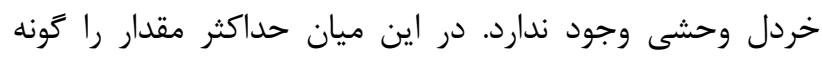

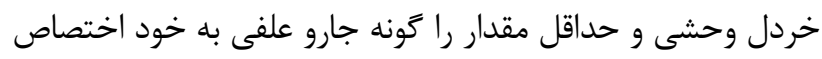

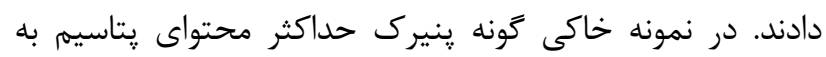

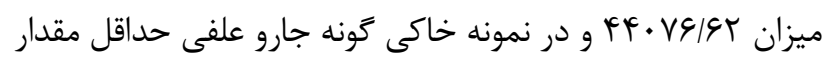

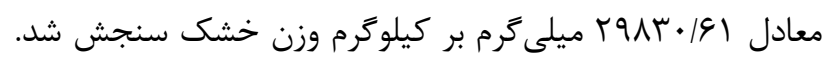

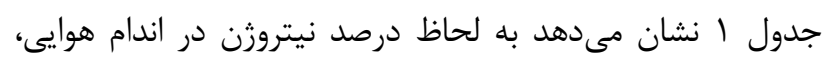

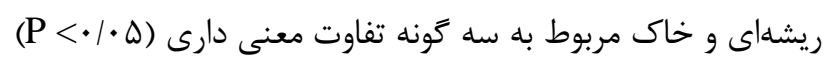

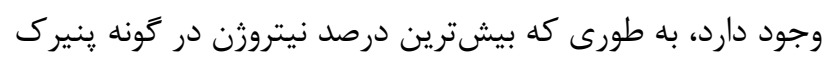

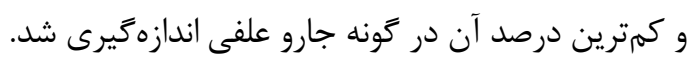
بررسى برخى شاخصهاى بيوشيميايى سه كونه تياهى

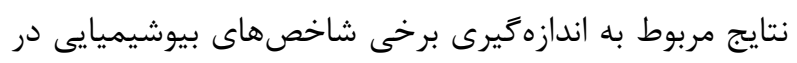

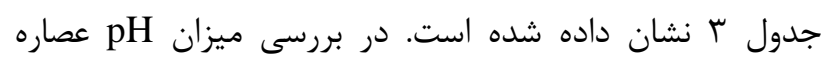

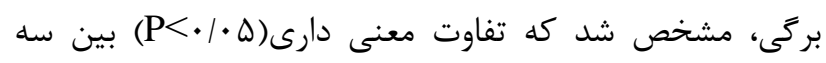

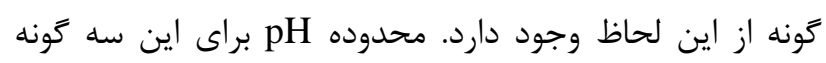

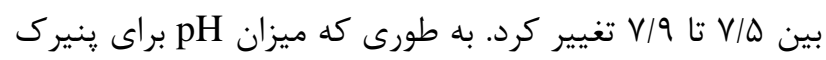

جدول ا- ميزان عناصر در اندام هوايى، ريشه و خاك سه گونه كياهى بر حسب ميلى

Table 1. Concentration of elements in shoot, root and soil of three plant species (mg. $\mathrm{kg}^{-1} \mathrm{DW}$ ).

\begin{tabular}{|c|c|c|c|}
\hline عناصر تحت مطالعه & $\begin{array}{c}\text { Malva neglecta } \\
\text { ينيرك }\end{array}$ & $\begin{array}{c}\text { Sinapis arvensis } \\
\text { خردل وحشى }\end{array}$ & $\begin{array}{c}\text { Bromus tectorum } \\
\text { جارو علفى }\end{array}$ \\
\hline آهن اندام هوايى & 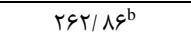 & $\Delta 9 / 8 /^{c}$ & $r q \cdot / 1 \mu^{a}$ \\
\hline آهن ريشهاى & $r \cdot \cdot / \cdot \Lambda^{b}$ & $q r r / 9 \Lambda^{a}$ & INA/A $\mathrm{r}^{\mathrm{b}}$ \\
\hline آهن خاك & $q \Lambda / \cdot r^{c}$ & $\mid F T / G q^{b}$ & $I V Y / V Y^{a}$ \\
\hline مس اندام هوايى & $F r / V V^{b}$ & $\Delta \Delta / r V^{\mathrm{a}}$ & $11 /\left.9\right|^{\mathrm{c}}$ \\
\hline مس ريشهاى & $I r \Delta / r \Delta^{\mathrm{a}}$ & $1.9 / 1 \mathrm{rb}^{\mathrm{b}}$ & $r \Lambda / V \Delta^{c}$ \\
\hline مس خاك & $I T / V r^{c}$ & $T F / r \Delta^{a}$ & $\mathrm{IV} / \Lambda \mathrm{r}^{\mathrm{b}}$ \\
\hline روى اندام هوايى & $V I / f^{a}$ & $\Delta Y_{/ \Lambda F^{b}}$ & $r q / 19^{c}$ \\
\hline روى ريشهاى & $V \cdot / V I^{a}$ & $81 / v \cdot{ }^{b}$ & $r \varepsilon / \cdot V^{c}$ \\
\hline روى خاك & $\left.|r \&|\right|^{a}$ & $11 T / K^{b}$ & $q F / \Delta V^{c}$ \\
\hline منَخنز اندام هوايى & $r / r \omega^{b}$ & $r / 4)^{b}$ & $r / 9 \Delta^{\mathrm{a}}$ \\
\hline منكَنز ريشهاى & $\cdot / 19^{\mathrm{b}}$ & $\cdot / 1 a^{\mathrm{b}}$ & $\cdot / r \cdot{ }^{a}$ \\
\hline منكَنز خاك & $\cdot / \mu^{a}$ & $\cdot|r|^{b}$ & $\cdot|r|^{b}$ \\
\hline فسفر اندام هوايى & $\Delta q \cdot 1 \cdot 1^{a}$ & $18 \cdot 1199^{c}$ & rGY/TKb \\
\hline فسفر ريشهاى & $19 \cdot / 11^{b}$ & $19 / \pi \Lambda^{c}$ & $119^{a}$ \\
\hline فسفر خاى & $r 199 / 9 r^{b}$ & $|f| V /\left.V\right|^{c}$ & $r \& V \cdot / r T^{a}$ \\
\hline يتاسيم اندام هوايى & $F \& \& V \cdot 1 \Delta q^{a}$ & $F \& q 91 / V \Delta^{a}$ & $|\Lambda F| \cdot \mid \Lambda \cdot b$ \\
\hline يتاسيم ريشهاى & $r \cdot \wedge V r^{b}$ & $r \Delta \Delta G \Psi / V g^{a}$ & $\mid F \Psi G \Lambda / F \Lambda^{c}$ \\
\hline يتاسيم خاى & $F F \cdot V \varepsilon / g Y^{a}$ & THFTE/DN & $r q \wedge r \cdot|8|^{c}$ \\
\hline \% نيتروثن اندام هوايى & $\Delta / \cdot \wedge^{\mathrm{a}}$ & $F / \Delta Y^{b}$ & $1 / \Delta Y^{c}$ \\
\hline \% نيتروثن ريشهاى & $1 / \pi r^{a}$ & $1 / \cdot 4^{b}$ & $\cdot / \pi v^{c}$ \\
\hline \% نيتروثن خاى & $\cdot / 1 \Delta V^{a}$ & $\cdot 1 \cdot 99^{b}$ & $.1 .4 q^{c}$ \\
\hline
\end{tabular}

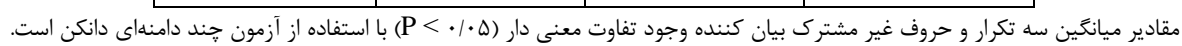

Data represent means of three replicates; different letters indicate significant differences at $\mathrm{P}<0.05$ using Duncan's test. 


$$
\text { جدول r- مقايسه فاكتورهاى انتقال و تغليظ زيستى گونههاى تحت مطالعه براى عناصر آهن، مس، روى و منگنز. }
$$

Table 2. Comparison of translocation and bioconcentration factors of studied species for Fe, $\mathrm{Cu}, \mathrm{Zn}$ and $\mathrm{Mn}$.

\begin{tabular}{|c|c|c|c|}
\hline فاكتورهاى انتقال و تغليظ زيستى & $\begin{array}{c}\text { Malva neglecta } \\
\text { ¥نيرك }\end{array}$ & $\begin{array}{c}\text { Sinapis arvensis } \\
\text { خردل وحشى }\end{array}$ & $\begin{array}{c}\text { Bromus tectorum } \\
\text { جارو علفى }\end{array}$ \\
\hline فاكتور انتقال آهن & $1 / \mathrm{T}^{\mathrm{b}}$ & $\cdot / / \mu^{\mathrm{c}}$ & $r / \cdot \varphi^{\mathrm{a}}$ \\
\hline فاكتور تغليظ زيستى آهن در اندام هوايى & $T / 9 V^{a}$ & $\cdot|4|^{\mathrm{c}}$ & $T / T^{b}$ \\
\hline فاكتور تغليظ زيستى آهن در بخش ريشهاى & $r / \cdot r^{b}$ & $r / \cdot r^{a}$ & $1 / \cdot \Lambda^{\mathrm{c}}$ \\
\hline فاكتور انتقال مس & $\cdot / \pi \Lambda^{\mathrm{a}}$ & $\cdot / 1 \Lambda^{b}$ & $\cdot / \cdot v^{\mathrm{c}}$ \\
\hline فاكتور تغليظ زيستى مس در اندام هوايى & $r / 1 l^{\mathrm{a}}$ & $T / T \varepsilon^{b}$ & $\cdot 19 \Delta^{\mathrm{c}}$ \\
\hline فاكتور تغليظ زيستى مس در بخش ريشهاى & $9 / 1 r^{a}$ & $r / r v^{b}$ & $r / I V^{c}$ \\
\hline فاكتور انتقال روى & $1 / \cdot 9^{\mathrm{a}}$ & $\cdot / \Lambda k^{b}$ & $\cdot|\mathrm{A}|^{\mathrm{b}}$ \\
\hline فاكتور تغليظ زيستى روى در اندام هوايى & $\cdot \mid \Delta \varphi^{\mathrm{a}}$ & $\cdot / 4 \mathrm{rb}$ & $\cdot / \pi \cdot c$ \\
\hline فاكتور تغليظ زيستى روى در بخش ريشهاى & $\cdot 1 \Delta \varphi^{\mathrm{a}}$ & $|\Delta|^{a}$ & $\cdot / r \Lambda^{b}$ \\
\hline فاكتور انتقال منگنز & $r \cdot / r \Delta^{\mathrm{a}}$ & $r / / 99^{a}$ & $M / A V^{a}$ \\
\hline فاكتور تغليظ زيستى منكَنز در اندام هوايى & $11 / 9 r^{b}$ & $19 / 4 f^{a}$ & $19 / 9 \cdot{ }^{a}$ \\
\hline فاكتور تغليظ زيستى منكَنز در بخش ريشهاى & $\cdot \mid \Delta \Lambda^{\mathrm{c}}$ & $\cdot / \mathrm{V}^{\mathrm{C}^{\mathrm{b}}}$ & $\cdot / 9 \Delta^{\mathrm{a}}$ \\
\hline
\end{tabular}

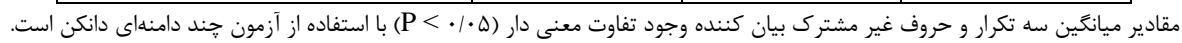

Data represent means of three replicates; different letters indicate significant differences at P > 0.05 using Duncan's test.

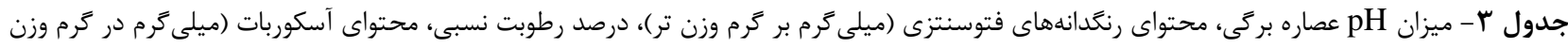

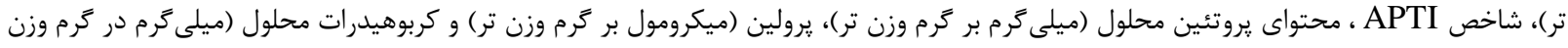

$$
\begin{aligned}
& \text { خشك) در سه گونه گياهى. }
\end{aligned}
$$

Table 3. The leaf extract pH, photosynthetic pigments content (mg.g-1 FW), relative humidity content (RWC), ascorbate content (mg.g-1 FW), APTI index, total soluble protein (mg.g-1 FW), proline ( $\mu$ mol. g-1 FW) and soluble

\begin{tabular}{|c|c|c|c|}
\hline شاخصها & $\begin{array}{c}\text { Malva neglecta } \\
\text { ينيرى }\end{array}$ & $\begin{array}{c}\text { Sinapis arvensis } \\
\text { خردل وحشى }\end{array}$ & $\begin{array}{c}\text { Bromus tectorum } \\
\text { جارو علفى }\end{array}$ \\
\hline كلروفيل a & $\cdot / \Delta \Lambda^{\mathrm{b}}$ & $1 / 1 \mathrm{~V}^{\mathrm{a}}$ & $\cdot / \pi \varphi^{c}$ \\
\hline كلروفيل b & $\cdot / r v^{a}$ & $\cdot / r V^{a}$ & $\cdot / r q^{b}$ \\
\hline كلروفيل كل & $.199^{\mathrm{b}}$ & $1 / \Delta \Delta^{a}$ &.$/ \Delta \Delta^{c}$ \\
\hline كاروتنوئيدها & $\mid Q F / \& \Psi^{a}$ & $M A / \Psi^{b}$ & $91 / 90^{b}$ \\
\hline آسكوربات اندام هوايى & $V \Delta / \wedge V^{a}$ & VA/GY & $V 4 / q^{b}$ \\
\hline آسكوربات ريشهاى & $V G / T \Delta^{\mathrm{a}}$ & $V F / 9 \Delta^{b}$ & $V F / q Y^{b}$ \\
\hline درصد رطوبت نسبى & $\mathrm{V} V / \Delta \mathrm{V}^{\mathrm{c}}$ & $\mathrm{Vq} / \mathrm{V} \mathrm{r}^{\mathrm{b}}$ & $\Lambda^{a}$ \\
\hline $\mathrm{pH}$ & $V / 9 \cdot{ }^{a}$ & $V / q V^{b}$ & $V / \Delta \Delta^{c}$ \\
\hline APTI & $V \Delta / \cdot V^{b}$ & $\mathrm{vg} / \mathrm{N} \cdot \mathrm{a}^{\mathrm{a}}$ & $9 N / V V^{\mathrm{C}}$ \\
\hline يروتئين اندام هوايى & $1 / V \Delta^{\mathrm{a}}$ & $1 / \pi r^{b}$ & $\cdot / V Y^{\mathrm{c}}$ \\
\hline يروتئين ريشهاى & $\cdot / \cdot \wedge^{\mathrm{a}}$ & $.1 .4^{b}$ & $.1 \cdot \mathrm{kc}^{\mathrm{c}}$ \\
\hline يرولين اندام هوايى & $\cdot / 9 Y^{c}$ & $r / \Delta r^{b}$ & $\Delta / 4 \cdot{ }^{a}$ \\
\hline يرولين ريشهاى & $1 / 9 \cdot^{c}$ & $f / 4 \varepsilon^{b}$ & $\Delta / \Delta \Lambda^{\mathrm{a}}$ \\
\hline كربوهيدرات & $\cdot 119^{\mathrm{C}}$ & $\cdot / \Delta V^{b}$ & $1 / 4^{a}$ \\
\hline
\end{tabular}
carbohydrates contents (mg.g-1 DW) in the three plant species.

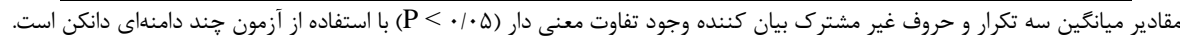

Data represent means of three replicates; different letters indicate significant differences at $\mathrm{P}<0.05$ using Duncan's test.

جارو علفى به ميزان \&N/VV محاسبه شد (جدول س). بر اساس نتايج اين يزوهش مشاهده شد كه بين سه كياه در بخش هوايى

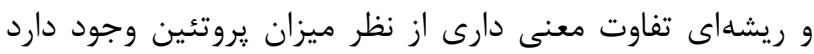

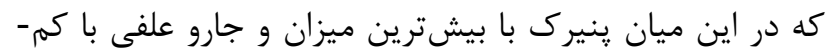
ترين ميزان :روتئين گزارش شدند (جدول با). مطابق با جدول r، بخش هاى هوايى و ريشهها به لحاظ محتواى يرولين سلولى
بين ميزان آسكوربات كل بخش هوايى و ريشهاى دو زياه جارو

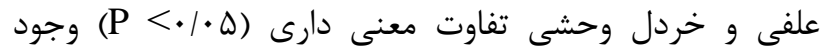
نداشت (جدول r). حداكثر ميزان اين شاخص در ينيرك سنجش شد. شاخص APTI بين سه گونه تفاوت معنى نشان داد، به اين صورت كه بيشترين ميزان اين شاخص درگونه

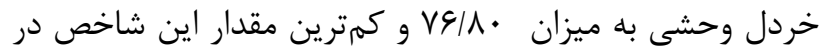




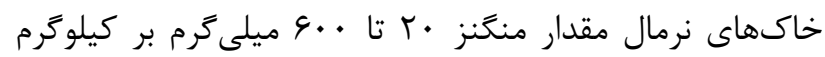

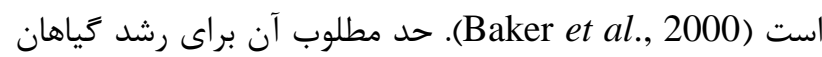

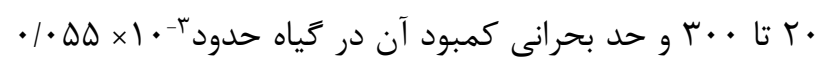
ميلى

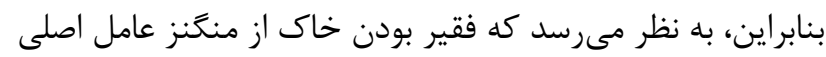

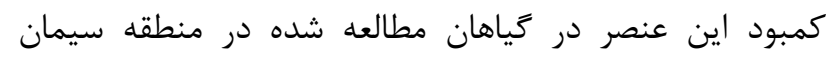

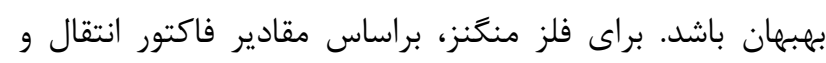

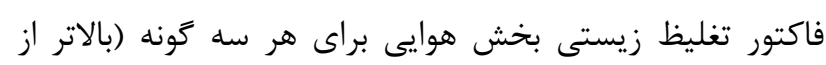

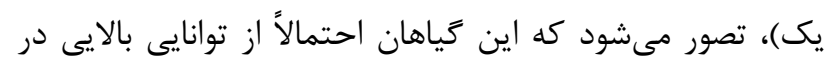

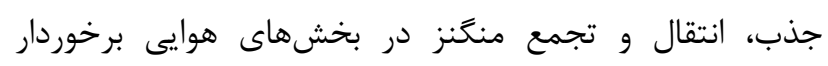

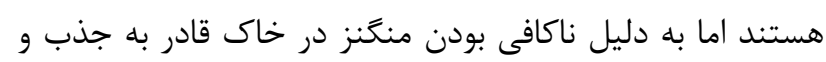

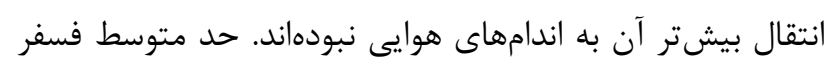

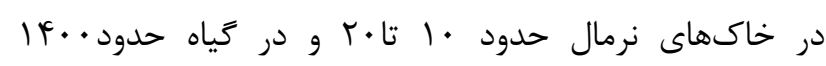

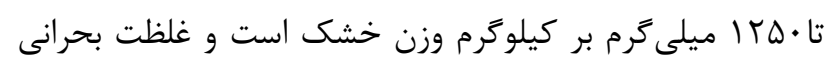

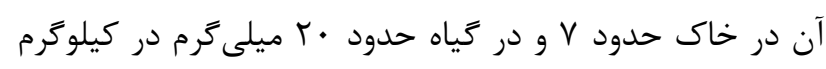

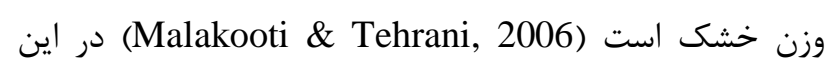
مطالعه عليرغم غلظت بالاى فسفر در خاى اطراف ريشه الفها، به

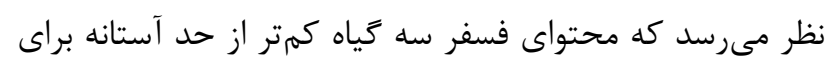

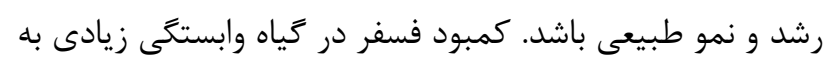

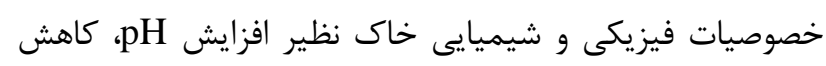

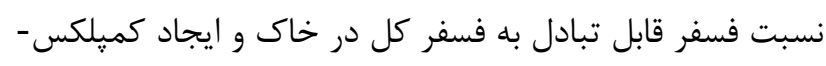

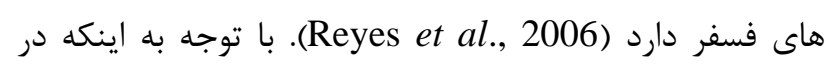

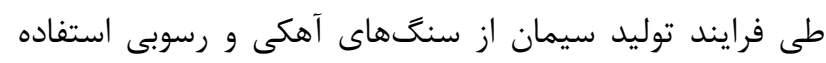

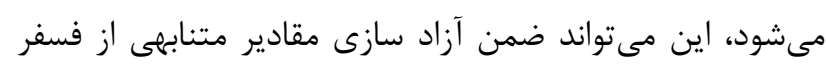

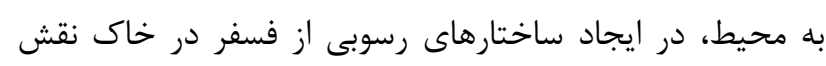

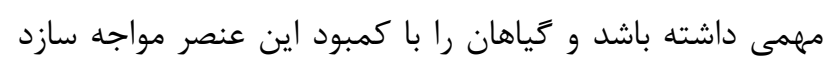

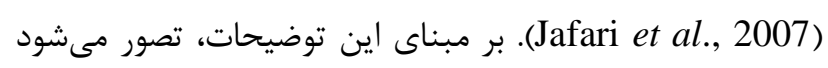

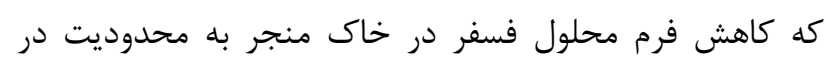

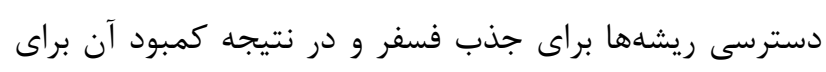

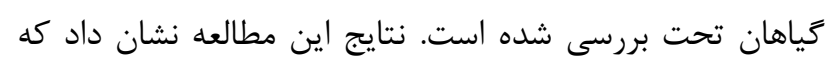

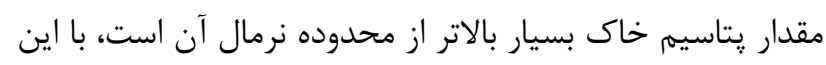

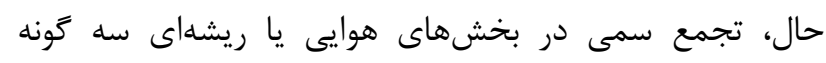

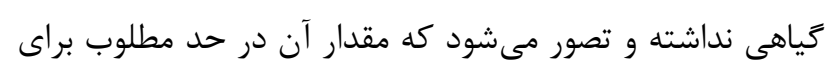

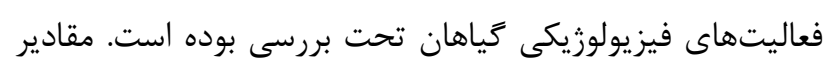

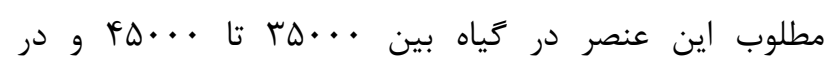

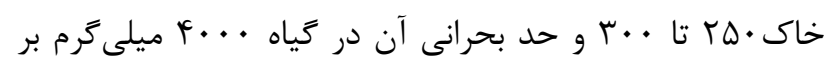

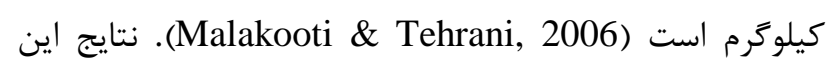

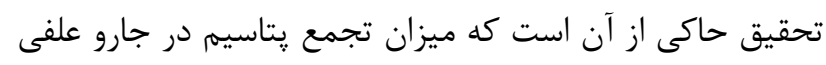

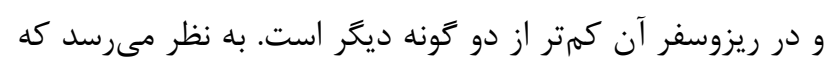

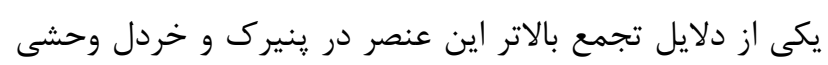

تفاوت معنى دارى (ه•|• P P) را بين سه گياه ارائه و حداكثر و

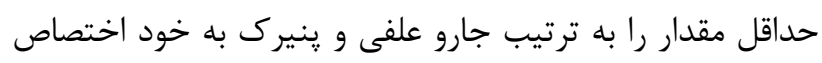

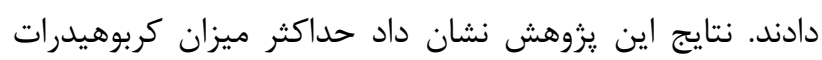

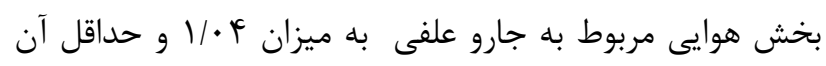

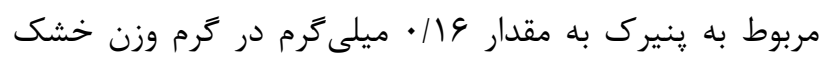

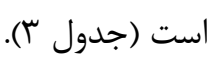

بحث

بر اساس نتايج حاصل از اين تحقيق، سنجش عناصر كم

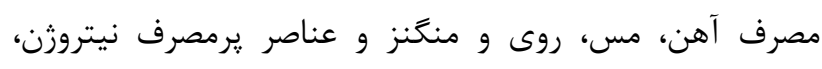

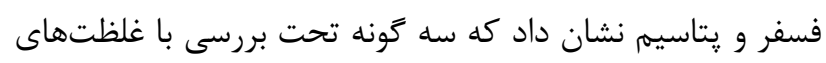

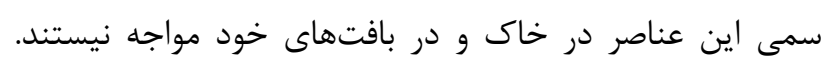
آهن، مس، روى و منكنز از جمله فلزات سنخينى هستند كه به ديه

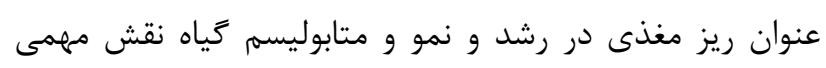

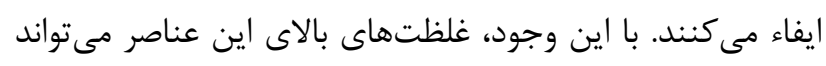
منجر به بروز آثار سميت در كياهان شود (Lin et al., 2012). نتايج اين بررسى مشخص كرد كه كمبود آهن، مس و ورو روى در

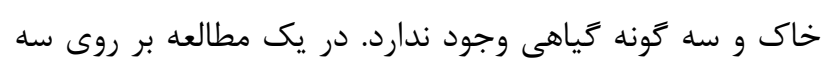

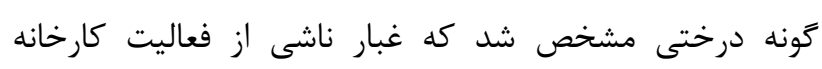

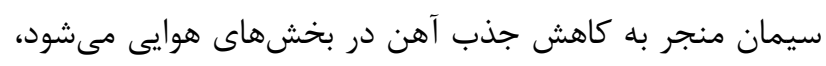

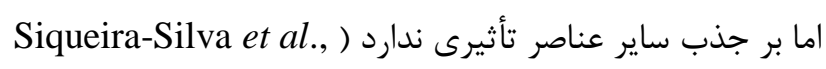

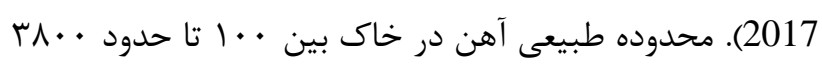

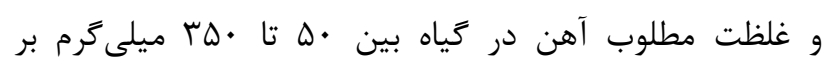
كيلوَّرم وزن خشك است (Malakooti \& Tehrani, 2006).

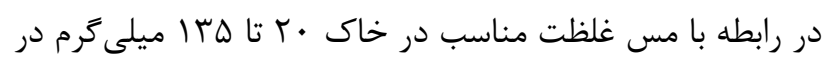
كيلوكرم وزن خشك كزارش شده است (Gerrard, 2000).

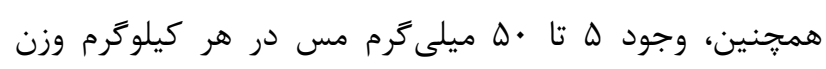

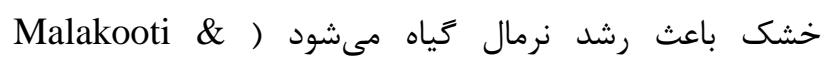

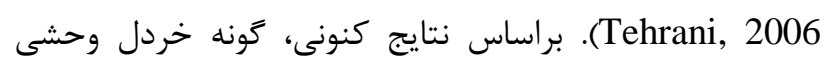
براى آهن و مس و گونه ينيرى براى عنصر مس مقائ مقادير فاكتور

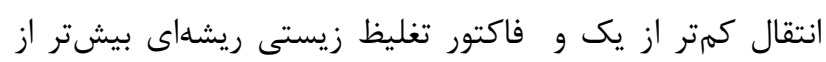

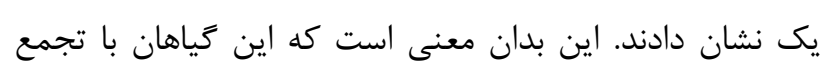

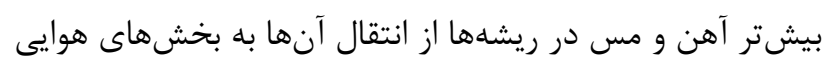

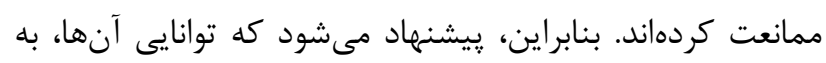

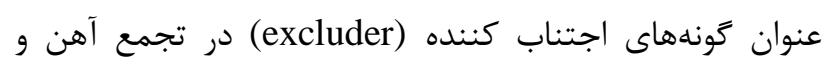

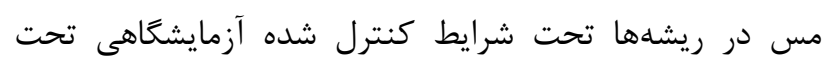

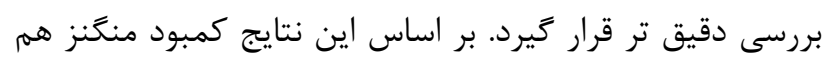

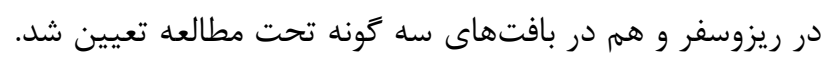

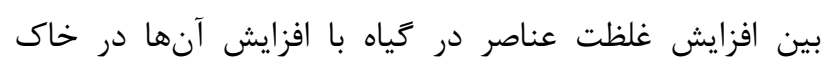

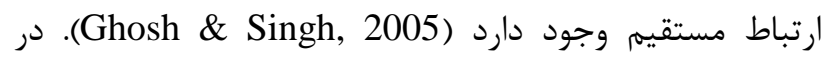


يرولين و كاروتنوئيدها به مراتب حساسيت كمترى را نسبت به شرايط محيطى از خود نشان داده است.

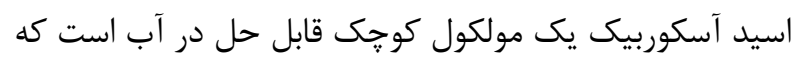

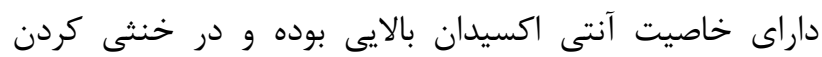

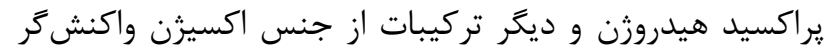

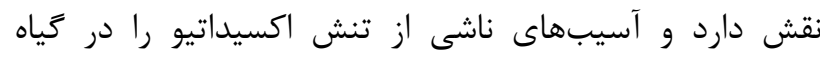

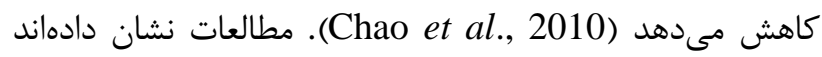
كه با افزايش آلودحى و غلظت فلزات سنگين، ميزان اين ماده در

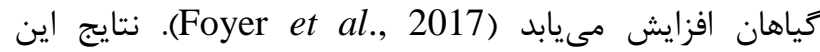

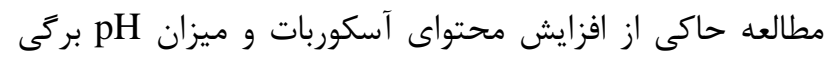

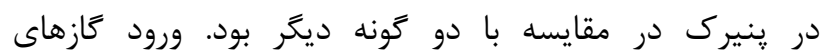

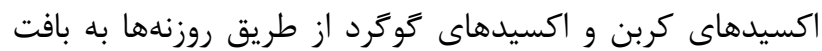

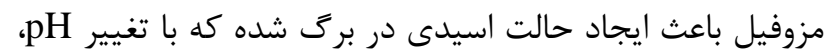

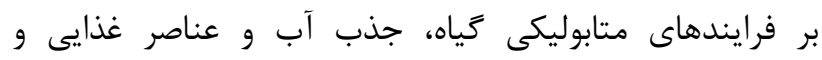
فراساختار سلولى اثر منفى دارد (Bamniya et al., 2012).

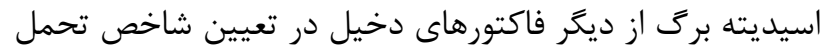

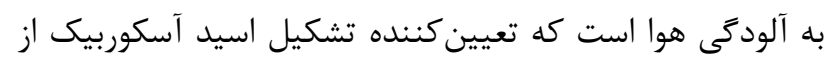

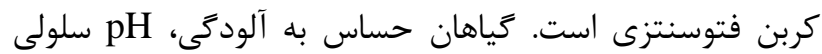
كمترى نسبت به كياهان متحمل داشتند ) Escobedoa et al.,

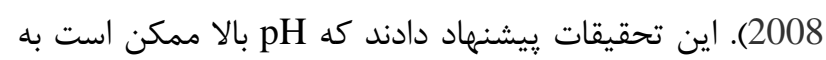
طور مؤثر باعث افزايش هدايت جريان كربن فتوسنتزى به سمت

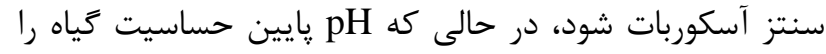

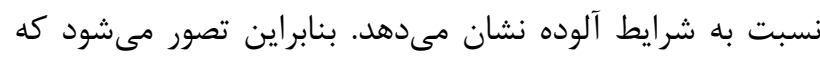

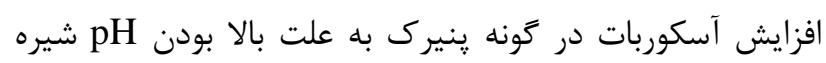
سلولى اين گَونه نسبت به دو گَونه ديكر و امكان بيشتر تبديل

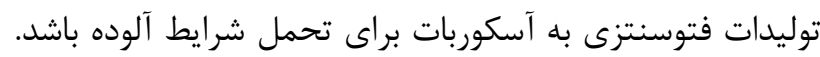

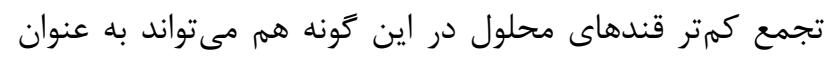

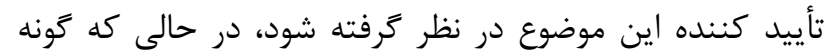
جارو علفى با كمترين محتواى آسكوربات بالاترين ميزان كربوهيدراتهاى محلول را از خود نشان داد (جدول بان).

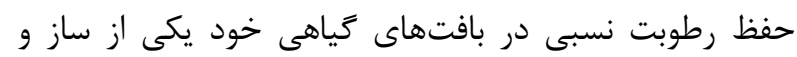

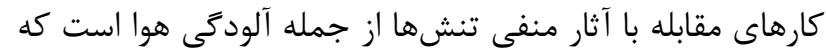
كياه به روشهاى مختلف نظير افزايش توليد اسموليتها مانند

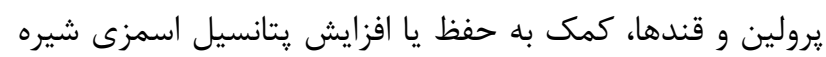

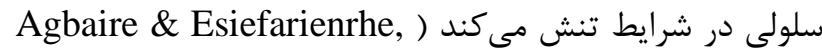
2009). در اين تحقيق جارو علفى حداكثر ميزان اين شاخص و

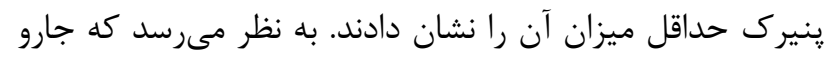

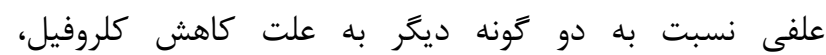

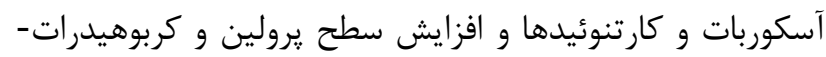
هاى محلول بيشتر تحت تأثير تنش بوده است. حال آن كه تصور
كاهش محتواى رطوبت نسبى (جدول ؟) در مقايسه با جارو

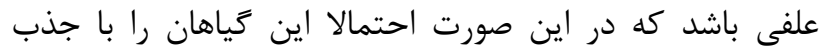
بيشتر ريتاسيم براى حفظ يتانسيل اسمزى مواجه ساخته است. همجنين اين مطالعه مشخص كرد كه كمبود نيتروزن در خاك اطراف ريشههاى سه كياه علفى مذكور وجود ندارد و مقدار آن

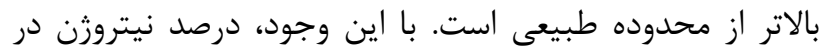

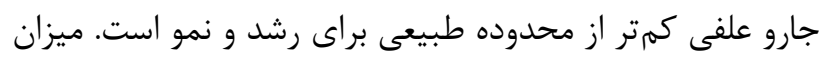

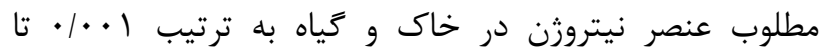

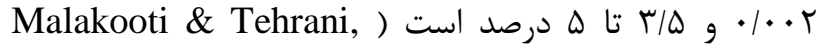

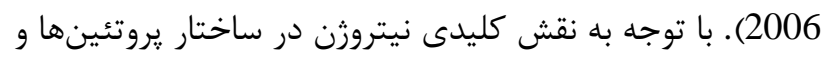

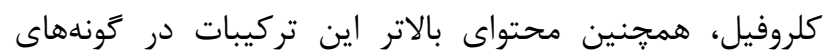
ينيرك و خردل وحشى در مقايسه با جارو علفى در اين مطالعه،

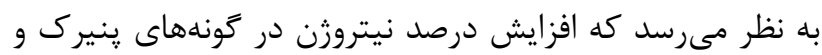

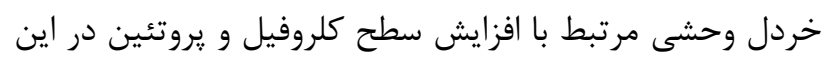
كياهان باشد (جدول ؟َ). محتواى كلروفيل براى فعاليتهاى فتوسنتزى بسيار ضرورى است، بنابراين كاهش مقدار كلروفيل

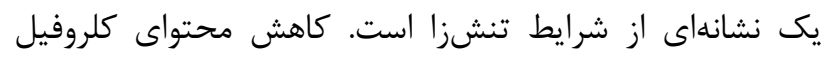
برى كياهان در حال رشد در مناطق صنعتى اتفاق مىافتد

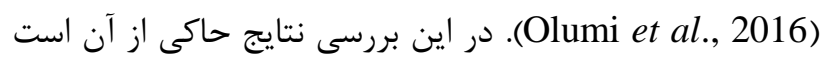

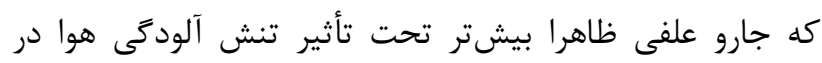

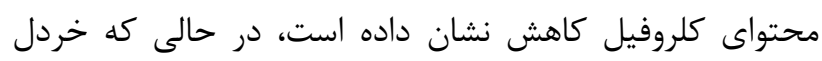
وحشى با محتواى بيشتر در كلروفيل a، b و كلروفيل كل به دانه

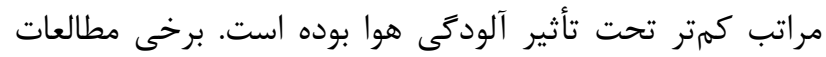

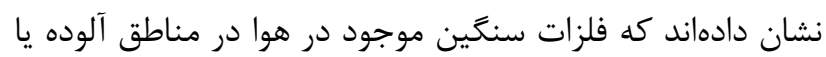
غبار كارخانه سيمان با جلوكيرى از جذب عناصر ضرورى مانند

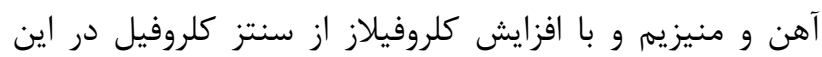

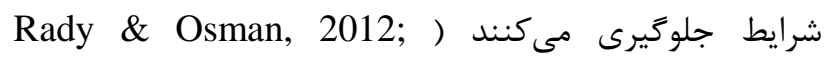
Siqueira-Silva et al., 2017 (S) بر برسى محتواى كارتنوئيدها

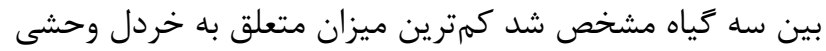

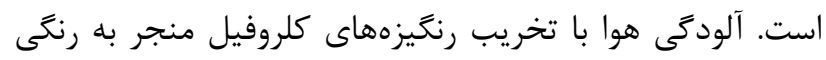

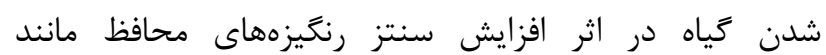
كاروتنوئيدها و آنتوسيانينها مىشود (Posmyk et al., 2009). كاروتنوئيدها هم به عنوان رنحدانههاى محافظ و هم به عندوان آنتان

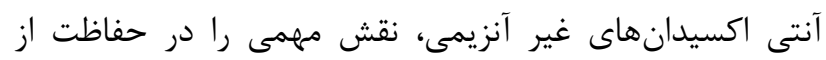

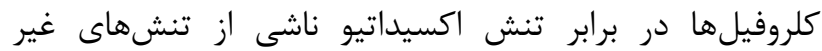
زيستى نظير آلودكى ايفا مىكنند ( Shafi Tantrey \&

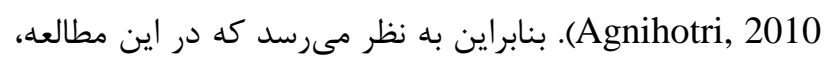

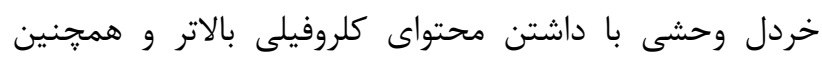

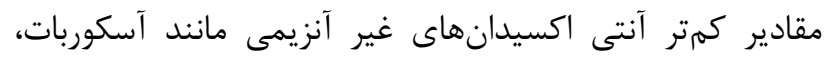


بافتهاى در حال ترميم، يك اسموليت مؤثر در تنظيم فشار

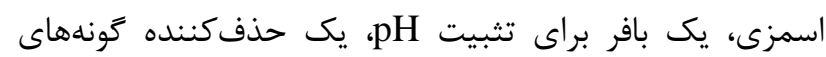
واكنش

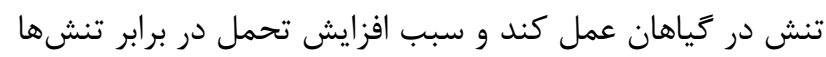

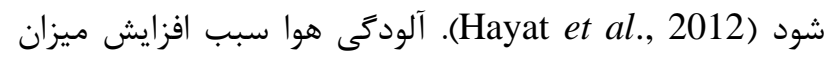

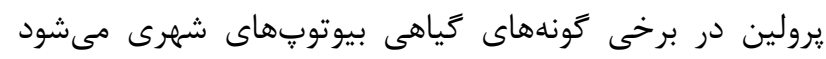

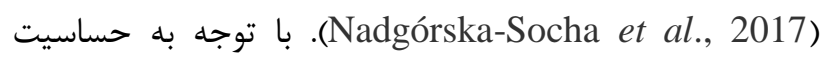

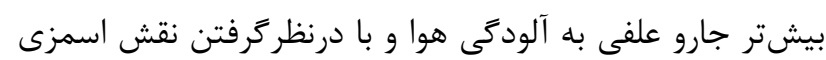

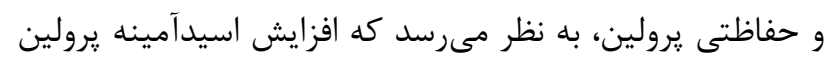

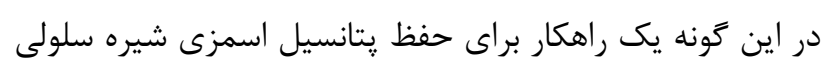

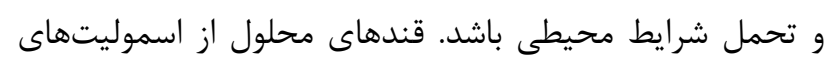

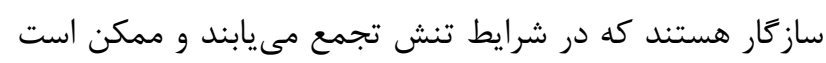

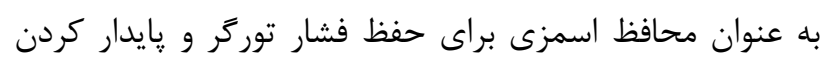
غشاها و يروتئينها عمل كنند (Zouari et al., 2016). مقدار

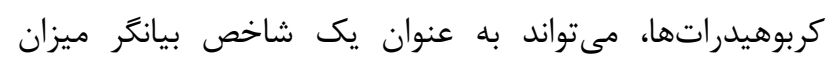

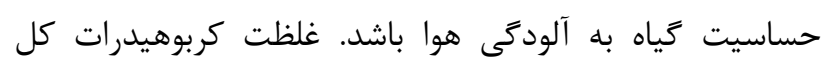

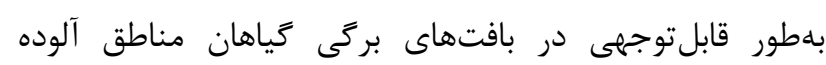

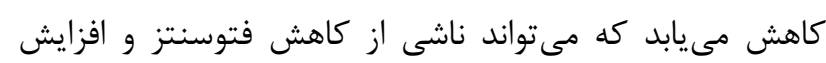

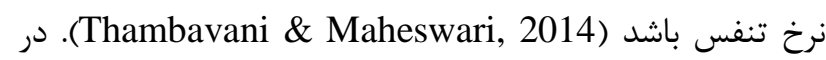
كياهان رشد يافته در مناطق آلوده، ميزان كربوهيدرات كل افزايش نشان مىدهد (Karmakar et al., 2016). بنابراين، افزايش ميزان كربوهيدراتهاى محلول در كونه جارو علفى تصور

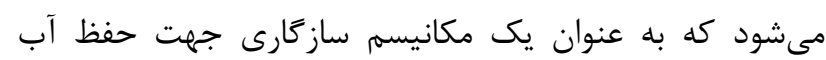
درون بافتى و حتى حفاظت از ساختمان ماكرومولكولهاى مهاى مهانه زيستى در اين شرايط باشد.

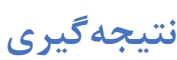

بلهطوركلى با ارزيابى برخى عناصر در سه كَّنه علفى و خاك

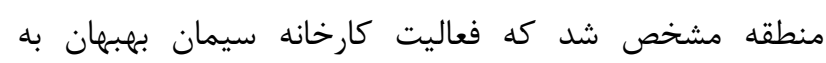

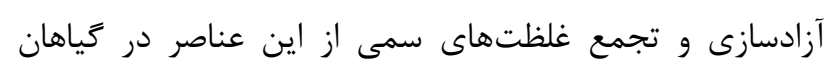

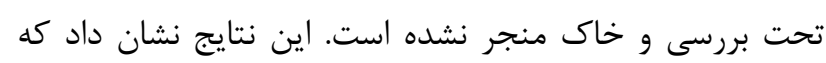

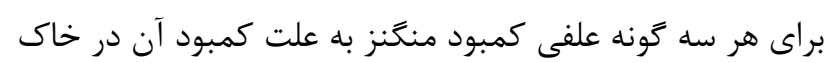

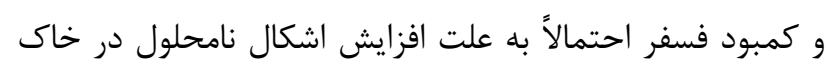

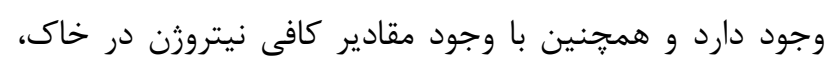

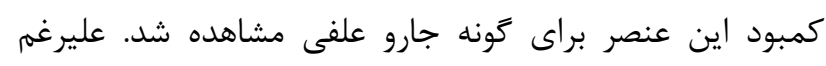

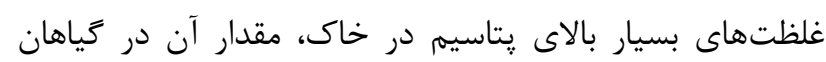

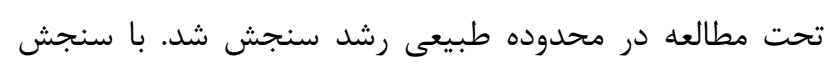

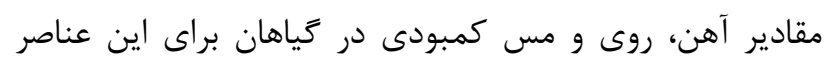

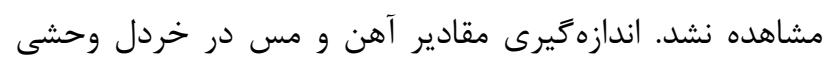

مىشود شرايط موجود براى گونه ينيرك در مقايسه با جارو علفى

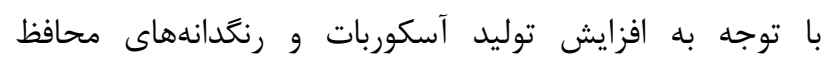

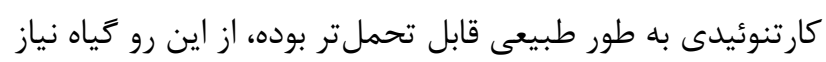

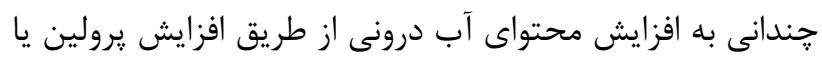
كربوهيدراتها نداشته است. شاخص تحمل به آلودكى هوا (APTI) توانايى يك كياه را براى

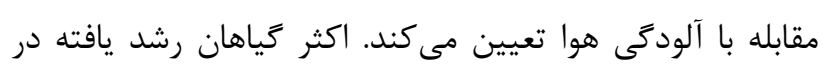

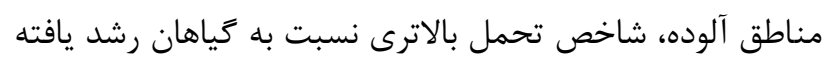

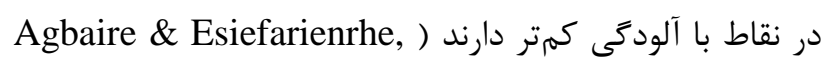

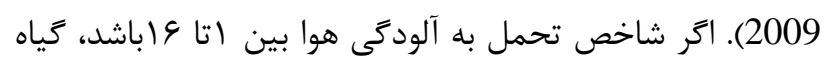
حساس به آلودگى است (Joshi et al., 2009). سال2003 با بررسى اين شاخص در زياهان رشد يافته در نقاط

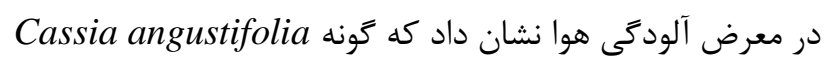

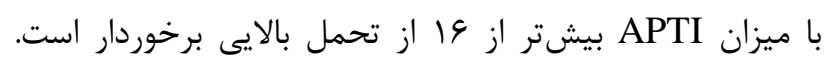

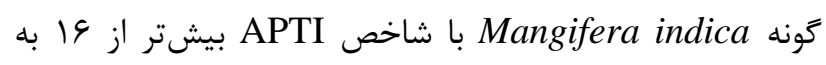

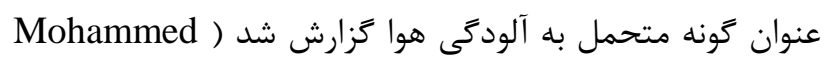

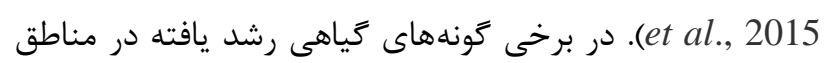

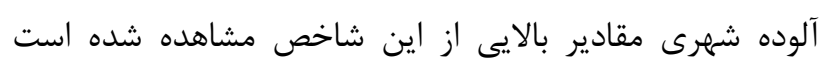

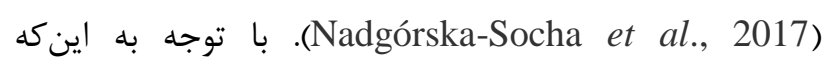

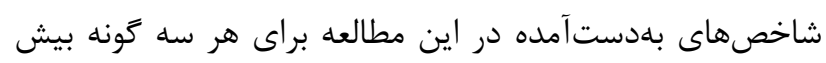

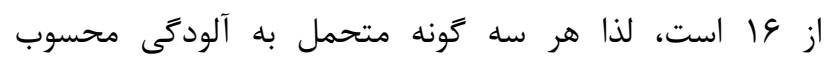

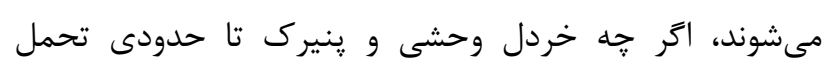
بيشترى را نسبت به جارو علفى نشان دادند.

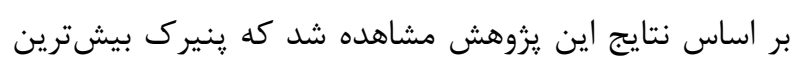

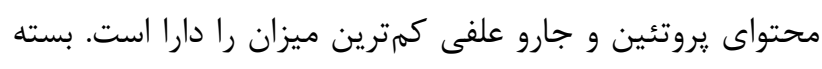

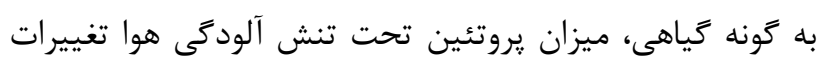

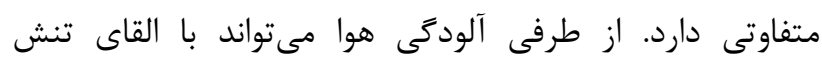

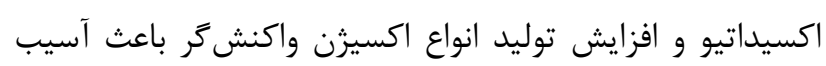
جدى به يروتئينها شود (Karmakar et al., 2016). مثلاً كزارش شده است كه برخى از آلايندهاى هوا از طريق تود توليد

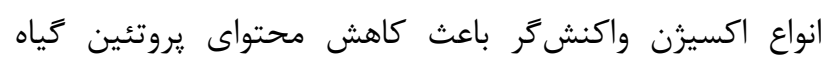

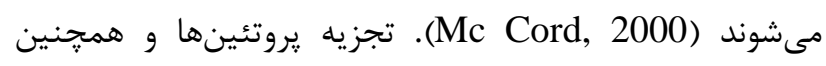

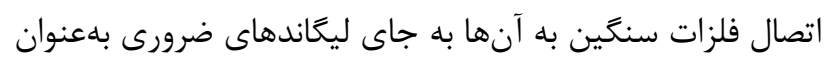

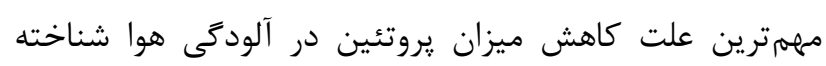
شده است ) ش

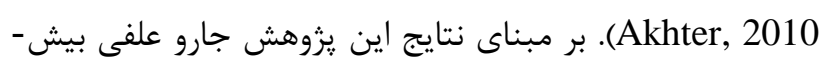

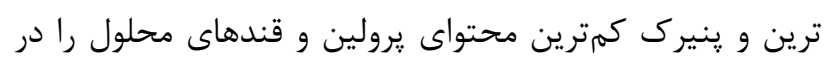

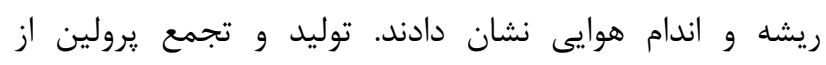
سازكارىهاى مهم در كياهان در شرايط تنش اكسيداتيو است.

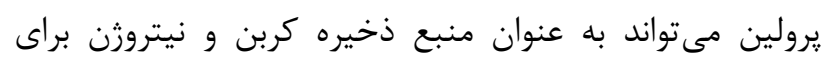


Foyer, C.H., Ruban, A.V. and Noctor, G. 2017. Viewing oxidative stress through the lens of oxidative signalling rather than damage. - Biochem. J. 474: 877-883.

Garcia-Lorenzo, M.L., Perez-Sirvent, C. MartinezSanchez, M.J. and Molina-Ruiz, J. 2012. Trace elements contamination in an abandoned mining site in a semiarid zone. - J. Geochem. Explor. 113: 23-35.

Gerrard, J. 2000. Fundamentals of soils (Routledge fundamentals of physical geography). - Routledge, New York. pp: 225.

Ghosh, M. and Singh, S.P. 2005. Comparative uptake and phytoextraction study of soil induced choromium by accumulator and high biomass weed species. ? App. Ecol. Environ. Res. 3: 67-79.

Hayat, S., Hayat, Q., Alyemeni, M.N., Shafi Wani, A., Pichtel, J. and Ahmad, A. 2012. Role of proline under changing environments. ? Plant Behav. 7: 14561466.

Hediat, M.H., Salama, M. Al-Rumaih, M. and Al-Dosary, M.A. 2011. Effect of Riyadh cement industry pollution on some physiological and morphological factors of Datura innoxia Mill. plant. ? Saudi J. Biol. Sci. 18: 227-237.

Igbal, M.Z. and Shafig, M. 2001. Periodical effect of cement dust pollution on the growth of some plants species. ? Turk. J. Bot. 25: 19-24.

Jafari, M., Zare Chahouki, M.A., Tavili, A. and Kohandel, A. 2007. Soil-vegetation relationships in rangelands of Qom province. ? Pajouhesh Sazandegi 19: 110-116.

Joshi, N., Chauhan, A. and Joshi, P.C. 2009. Impact of industrial air pollutants on some biochemical parameters and yield in wheat and mustard plants. ? Environmentalist 29: 398-404.

Karmakar D, Malik N, and Padhy, P.K. 2016. Effects of industrial air pollution on biochemical parameters of Shorea robusta and Acacia auriculiformis. ? Res. J. Recent Sci. 5: 29-33.

Kjeldahl, J.Z. 1883. A new method for the determination of nitrogen in organic bodies. ? Anal. Chem. 22: 366.

Kovacs, B., Gyori, Z., Prokisch, J., Loch, J. and Daniel, P. 1996. A study of plant sample preparation and inductively coupled plasma emission spectrometry parameters. ? Commun. Soil Sci. Plant Anal. 27: 1177-1198.

Latrou, M., Papadopoulos, F., Papadopoulos, O., Dichala, P., Psoma, P. and Bountla, A. 2014. Determination of soil available phosphorus using the Olsen and Mehlich 3 method for Greek soils having variable amounts of calcium carbonate. ? Commun. Soil Sci. Plant Anal. 45: 2207-2214.

Lichtenthaler, H.K. 1987. Chlorophylls and carotenoids: Pigments of photosynthetic biomembranes. ? Methods Enzymol. 148: 350-382.

Lin, W., Xiao, T., Wu, Y., Ao, Z. and Ning, Z. 2012. Hyperaccumulation of zinc by Corydalis davidii in Zn-polluted soils. ? Chemosphere 86: 837-84.

Lindsay, W.L. and Norvell, W.A. 1978. Development of a DTPA test for zinc, iron, manganese and copper. ? Soil Sci. Soc. Am. J. 42: 421-428.
Malakooti, M.J. and Tehrani, M.M. 2006.The role of micronutrients in increasing yield and improving the quality of agricultural products (microelements with enormous impact). ? Tarbiat Modares University Press, Tehran.

Mandre, M. and Klos Eiko, J. 1997. Changes carbohydrate partitioning in 6- year- old coniferous trees after proloneged exposure of cement dust. ? Z $\mathrm{Z}$. Naturforsch B. J. Chem. Sci. 52:1-9.

Mc Cord, J.M. 2000. The evolution of free radicals and oxidative stress. ? Am.J. Med. 108: 652-659.

Mohammed, M.A., Adamu, A.M. and Borkoma, M.B. 2015. Determination of air pollution tolerance index of selected trees in selected location in Maiduguri. ? App. Res. J. 1: 378-383.

Mukherjee, S.P. and Choudhuri, M.A. 1983. Implications of water stress-induced changes in the levels of endogenous ascorbic acid and hydrogen peroxide in Vigna seedlings. ? Physiol. Plant. 58: $166-170$.

Nadgórska-Socha, A., Kandziora-Ciupa, M., Trzęsicki, M. and Barczyk, G. 2017. Air pollution tolerance index and heavy metal bioaccumulation in selected plant species from urban biotopes. ? Chemosphere 183: 471-482.

Nelson, G.D. and Ilias, I.F. 2007. Effect of inert dust on olive (Olea europaea L.) leaf physiological parameters. ? Environ. Sci. Pollut. Res. Int. 14: 212214.

Olumi, H., Rezanejad, F. and Keramat, B. 2016. Comparative study of biochemical parameters of Pinus nigra and $P$. elderica cultivated in the area around Sarcheshmeh Copper Complex and Kantuyeh. 7 J. Iran. Plant Ecophysiol. Res.10: 1-12.

Pathak, V., Tripathi, B.D. and Mishra, V.K. 2011. Evaluation of Anticipated Performance Index of some tree species for green belt development to mitigate traffic generated noise. ? Urban Forest. Urban Green. 10: 61-66.

Pollard, J., Reeves, R.D. Baker, A.J.M. 2014. Facultative hyper accumulation of heavy metals and metalloids. ? Plants Sci. 217-218: 8-17.

Posmyk, M.M., Kontek, R. and Janas, K.M. 2009. Antioxidant enzymes activity and phenolic compounds content in red cabbage seedlings exposed to copper stress. ? Ecotoxicol. Environ. Saf. 72:596-602.

Qiu, R.L., Zhao, X., Tang, X.Z., Yu, F.M. and Hu, P.J. 2008. Antioxidative response to $\mathrm{Cd}$ in a newly discovered cadmium hyperaccumulator, Arabis paniculata $\mathrm{F}$. 目 Chemosphere 74: 6-12.

Rady, M.M. and Osman, A.S. 2012. Response of growth and antioxidant system of heavy metal-contaminated tomato plants to 24-epibrassinolide. ? Afr. J. Agric. Res. 7: 3249-3254.

Reyes, I., Valery, A. and Valduz, Z. 2006. Phosphatesolubilizing microorganisms isolated from rhizospheric and bulk soils of colonizer plants at an abandoned rock phosphate mine. ? Plant Soil 287: 69-75.

Sajadinia, S.A., Basiri, R., Fayyaz, P. and Moradi, M. 2016. Morphological and physiological impacts of 
cement kiln particle on Ziziphus spina-christi L. ? Iran. J. Forest 8: 79-89.

Semhi, K., Al-Khirbash, S., Abdalla, O., Khan, T., Duplay, J., Chaudhuri, S. and Al-Saidi, S. 2010. Dry atmospheric contribution to the plant-soil system around a cement factory: spatial variations and sources, a case study from Oman. ? Water Air Soil Pollut. 205: 343-357.

Shafi Tantrey, M. and Agnihotri, R.K. 2010. Chlorophyll and proline content of gram (Cicer arietinum L.) under cadmium and mercury treatments. ? Res. J. Agric. Sci. 1: 119-122.

Siqueira-Silva, A.I., Pereira, E.G., de Lemos-Filho, J.P., Modolo, L.V. and Paiva, E.A.S. 2017. Physiological traits and antioxidant metabolism of leaves of tropical woody species challenged with cement dust. ? Ecotoxicol. Environ. Saf. 144: 307-314.

Skelly, J.M. 2003. Native plants as bioindicators of air pollutants: contributed papers to a symposium held in conjunction with the 34th air pollution workshop. ? Environ. Pollut. 125:1-2.

Soon, Y.K. and Abboud, S. 1993 Cadmium, chromium, lead and nickel. In: Carter MR (ed.), Soil sampling and methods of analysis, 101-109. ? Lewis Publishers CRC, Boca Raton.

Thambavani, D.S. and Maheswari, J. 2014. Response of native tree species to ambient air quality. ? Chem. Sci. Trans. 3: 438-444.

Tripathi, A.K. and Gautam, M. 2007. Biochemical parameters of plants as indicators of air pollution. ? $\mathrm{J}$. Environ. Biol. 28: 127-132.

Yanqun, Z., Yuan, L., Schvartz, C., Langlade, L. and Fan, L. 2004. Accumulation of $\mathrm{Pb}, \mathrm{Cd}, \mathrm{Cu}$ and $\mathrm{Zn}$ in plants and hyperaccumulator choice in Lanping leadzinc mine area, China. ? Environ. Int. 30: 567-576.

Zouari, M., Ahmed, C.B., Elloumi, N., Bellassoued, K., Delmail, D., Labrousse, P., Abdallah, F.B. and Rouina, B.B. 2016. Impact of proline application on cadmium accumulation, mineral nutrition and enzymatic antioxidant defense system of Olea europaea L. cv Chemlali exposed to cadmium stress. ? Ecotoxicol. Environ. Saf. 128: 195-205.

How to cite this article:

Masoudizadeh, M., Zoufan, P. and Rastegarzadeh. S. 2020. The effects of Behbahan cement factory activity on the absorption of some nutrients and biochemical responses in herbaceous plants Sinapis arvensis, Malva neglecta and Bromus tectorum. - Nova Biol. Reperta 6: 464-477. (In Persian)

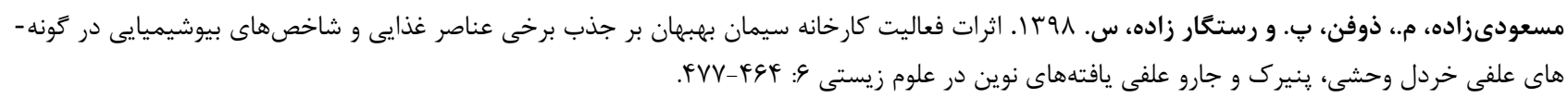

